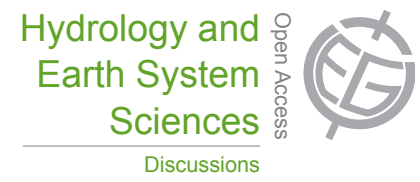

This discussion paper is/has been under review for the journal Hydrology and Earth System Sciences (HESS). Please refer to the corresponding final paper in HESS if available.

\title{
A comparison between remotely-sensed and modelled surface soil moisture (and frozen status) at high latitudes
}
I. Gouttevin ${ }^{1,2,3,4}$, A. Bartsch ${ }^{5,6,{ }^{*}}$, G. Krinner ${ }^{2,3}$, and V. Naeimi ${ }^{5}$
${ }^{1}$ Irstea, Unité de Recherche Hydrologie-Hydraulique, 5 rue de la Doua, CS 70077, 69626 Villeurbanne Cedex, France
${ }^{2}$ CNRS, LGGE, UMR5183, 38041, Grenoble, France
${ }^{3}$ Univ. Grenoble Alpes, LGGE, UMR5183, 38041, Grenoble, France
${ }^{4}$ CRYOS School of Architecture, Civil and Environmental Engineering, École Polytechnique Fédérale de Lausanne, Lausanne, Switzerland
${ }^{5}$ Research Group Remote Sensing, Department of Geodesy and Geoinformation, Vienna University of Technology, Gusshausstrasse 27-29, 1040 Vienna, Austria
${ }^{6}$ Austrian Polar Research Institute, c/o Universität Wien, Althanstraße 14, 1040 Vienna, Austria "currently at: Department of Geography, Ludwig-Maximilians-University Munich, Luisenstr. 37, 80333 München, Germany

\section{HESSD}

10, 11241-11291, 2013

Remotely-sensed and modelled surface soil moisture at high

latitudes

I. Gouttevin et al.

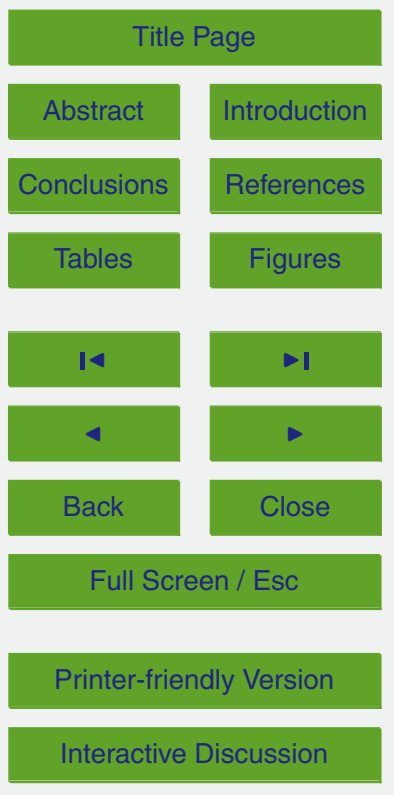

Interactive Discussion 
Received: 29 June 2013 - Accepted: 19 August 2013 - Published: 27 August 2013

Correspondence to: I. Gouttevin (isabelle.gouttevin @gmail.com)

Published by Copernicus Publications on behalf of the European Geosciences Union.

HESSD

10, 11241-11291, 2013

Remotely-sensed and modelled surface soil moisture at high latitudes

I. Gouttevin et al.

Title Page

Abstract Introduction

Conclusions

References

Tables

Figures

14

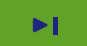

4

Back

Close

Full Screen / Esc

Printer-friendly Version

Interactive Discussion 


\section{Abstract}

In this study, the combined surface status and surface soil moisture products retrieved by the ASCAT sensor within the ESA-DUE Permafrost project are compared to the hydrological outputs of the land surface model ORCHIDEE over Northern Eurasia. The 5 objective is to derive broad conclusions as to the strengths and weaknesses of hydrological modelling and, to a minor extent, remote sensing of soil moisture over an area where data is rare and hydrological modelling is though crucial for climate and ecological applications. The spatial and temporal resolutions of the ASCAT products make them suitable for comparison with model outputs.

10 Modelled and remotely-sensed surface frozen and unfrozen statuses agree reasonably well, which allows for a seasonal comparison between modelled and observed (liquid) surface soil moisture. The atmospheric forcing and the snow scheme of the land surface model are identified as causes of moderate model-to-data divergence in terms of surface status.

15 For unfrozen soils, the modelled and remotely-sensed surface soil moisture signals are positively correlated over most of the study area. The correlation deteriorates in the North-Eastern Siberian regions, which is consistent with the lack of accurate model parameters and the scarcity of meteorological data. The model shows a reduced ability to capture the main seasonal dynamics and spatial patterns of observed surface soil moisture in Northern Eurasia, namely a characteristic spring surface moistening resulting from snow melt and flooding. We hypothesize that these weak performances mainly originate from the non-representation of flooding and surface ponding in the model. Further identified limitations proceed from the coarse treatment of the hydrological specificities of mountainous areas and spatial inaccuracies in the meteorological to determine to which extent plausible inaccuracies in the satellite data could also contribute to the diagnosed model-to-data discrepancies.
HESSD

10, 11241-11291, 2013

Remotely-sensed and modelled surface soil moisture at high latitudes

I. Gouttevin et al.

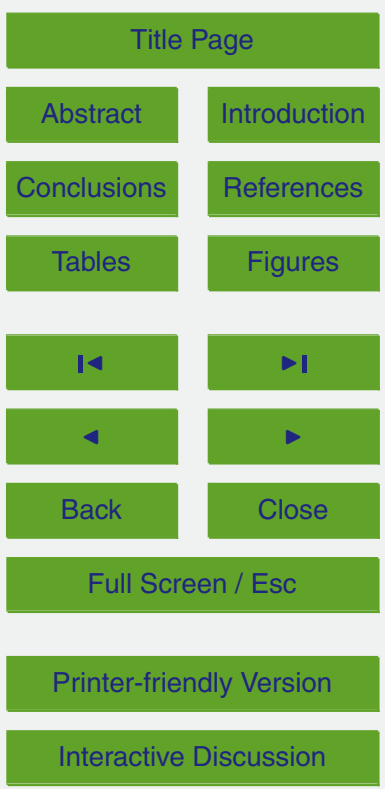




\section{Introduction}

Surface and subsurface soil moisture are key variables of the hydrological cycle and climate. Subsurface saturation degree will for instance partly control soil evaporation, the partition of rainfall water into infiltration and runoff, the dynamics of river discharges, 5 the thermal properties of the soil; on the other hand, the amount of plant-available water stored in the root zone will influence plant phenology and transpiration. In the carbon cycle, soil moisture is a key driver of the partition between oxic and anoxic soil decomposition processes, which respectively lead to atmospheric emissions of $\mathrm{CO}_{2}$ and methane, greenhouse gases with significantly different life-times and global 10 warming potentials (Forster et al., 2007). The amount of carbon stored in high-latitude soils (e.g. Tarnocai et al., 2009), and the extreme sensitivity of ecosystem dynamics to hydrological conditions (e.g. Schuur et al., 2008), make a proper understanding and modelling of the hydrological cycle in these regions even more crucial. Large areas of the boreal and Arctic regions are also underlain by permafrost, which can be very sensitive to variations in subsurface conditions affecting thermal properties and the potential for latent heat exchange. Soil water content is one of these conditions and thus is important to determine permafrost extent and evolution (e.g. Marchenko et al., 2008), which is another major uncertainty of climate projections (Friedlingstein et al., 2006).

20 Within global climate models, land surface models are dedicated to the representation of terrestrial processes, including surface and sub-surface hydrology. However, it has always been difficult to evaluate the ability of land surface models to represent soil moisture, because available data is scarce and of limited spatial representativity: this data usually comes in the form of point-measurements sampling field sites of moderate spatial extent, and which cover only a limited diversity of landforms, land-cover and climatic conditions (Ceballos et al., 2005; Georgakakos and Baumer, 1996). Soil moisture besides exhibits a very high spatial variability at scales from milimeters to kilometers, which hinders or limits the possibility of upscaling point-measurements to achieve
HESSD

10, 11241-11291, 2013

Remotely-sensed and modelled surface soil moisture at high latitudes

I. Gouttevin et al.

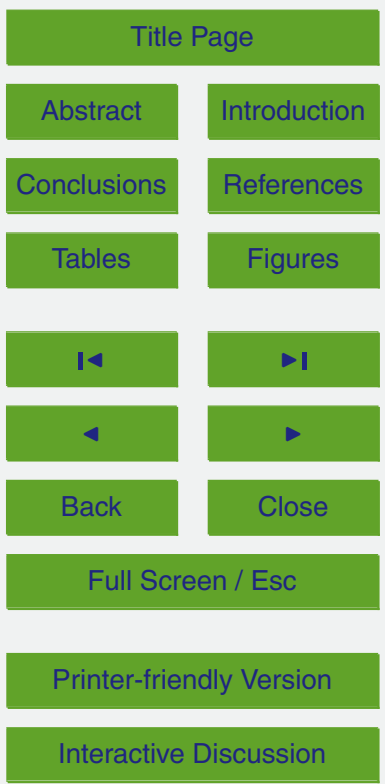


spatial averages for the whole globe (e.g. Schulin et al., 1992; Martinez-Fernandez and Ceballos, 2005; Wagner et al., 2008). At high latitudes, field measurements are even scarcer due to remoteness and difficult climate conditions; the poor knowledge of ecosystems and soil characteristics make spatial extrapolations of soil moisture condi5 tions hazardous.

Land-surface models work with typical grid-cells of $\sim 100 \mathrm{~km} \times 100 \mathrm{~km}$, within which some spatial variability can be accounted for, in terms of vegetation cover, snow cover, soil texture or altitude. The modelled soil moisture output is then at best a grid-cell average of soil moisture conditions computed separately on each subgrid homogeneous 10 patch. A comparable product can hardly be derived from point measurements for all regions of the globe due to the limitations mentioned above.

Another limitation of model-to-data comparisons at the model scale stems from the intrinsic philosophy of land surface models, which rely on effective (rather than ground truth) parameterisations to achieve reasonable values for their most important state variables or fluxes. The premise of physically-based modelling is that improving the physical description of the relevant processes will help represent reasonable fluxes and state variables. However, the necessary simplification performed with respect to reality implies that some of these fluxes and variables, including soil moisture, remain effective variables, tied to parameterization choices. Their absolute values can not be directly compared to observations, but should reflect observed trends and dynamics (Koster et al., 2009). Such a comparison can though help identify unexpected flaws or systematic biases in the model and open the path for further improvements. Regarding soil moisture, such improvements have long been hampered by the lack of evaluation data (Dirmeyer, 1995; Blöschl and Sivapalan, 1995).

As a result of limited soil moisture data availability and scale differences, the hydrological evaluation of land-surface models at large scales is often performed not on the soil moisture variable directly, but through comparisons between modelled and observed aggregated water fluxes (evapotranspiration, river discharges, e.g. Nijssen et al., 2003; Ringeval et al., 2012; Gouttevin et al., 2012). This approach is not fully
HESSD

$10,11241-11291,2013$

Remotely-sensed and modelled surface soil moisture at high latitudes

I. Gouttevin et al.

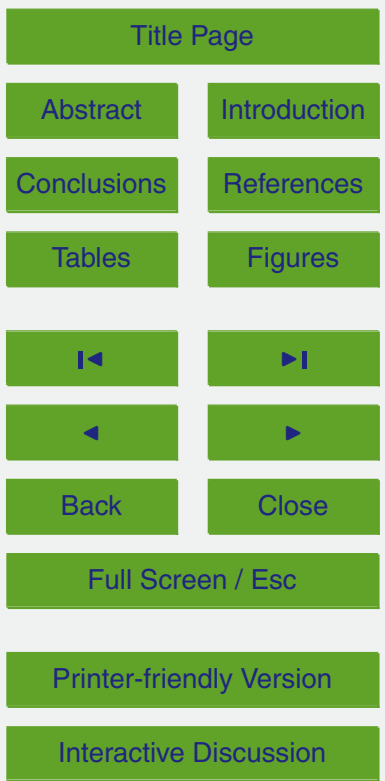


satisfactory as it leaves room for possible error compensations, especially when soil moisture is the variable of interest (e.g. for ecosystemic \& carbon-related applications).

Comparisons of modelled soil moisture to point-measurements (or spatially aggregated point-measurements) are also regularly performed to assess the physical con5 sistency and performances of the hydrological schemes in a controlled, well-known environment (e.g. Schlosser et al., 2000; Sitch et al., 2003; Pellarin et al., 2006). However, the performances assessed in these conditions can hardly be extrapolated to large regions of the world where detailed environmental knowledge is not available. This latter scale is though of primary interest for climate modelling.

10 Thanks to recent advances in remote-sensing techniques and retrieval algorithms, surface soil moisture can now be monitored globally using satellites. The satellite derived soil moisture products are by essence areal averages; the spatial scale of some of these products is comparable to the resolution of land surface models (Wagner et al., 2007a). Furthermore, data are acquired at frequencies higher than most in-situ 15 measurements.

Among these datasets, the soil moisture products derived from the SCAT (onboard the ERS-1 \& ERS-2 satellites) and the ASCAT (onboard MetOp satellite) instruments are particularly suited for comparison to model output at high latitudes due to their spatial resolution (25 to $50 \mathrm{~km}$ ), global coverage and temporal sampling ( $80 \%$ daily global coverage; Naeimi et al., 2009b). Several local to regional-scale analyses have shown the skill of these products to capture the observed soil moisture dynamics in the few areas of the world where a dense network of field measurements exists (Wagner et al., 2007b; Pellarin et al., 2006; Rüdiger et al., 2006). Most of them are located in temperate or tropical climate. The effective use of remotely-sensed surface soil moisture products in assimilation mode by hydrological or weather forecast models additionally revealed the potential of such datasets for hydrological modelling (Scipal et al., 2008; Yang et al., 2007; Reichle and Koster, 2005; Walker and Houser, 2004).

Up to now, very few studies have however focused on the large-scale remotelysensed and modelled surface soil moisture over high-latitude regions (Bartsch et al.,

\section{HESSD}

10, 11241-11291, 2013

Remotely-sensed and modelled surface soil moisture at high latitudes

I. Gouttevin et al.

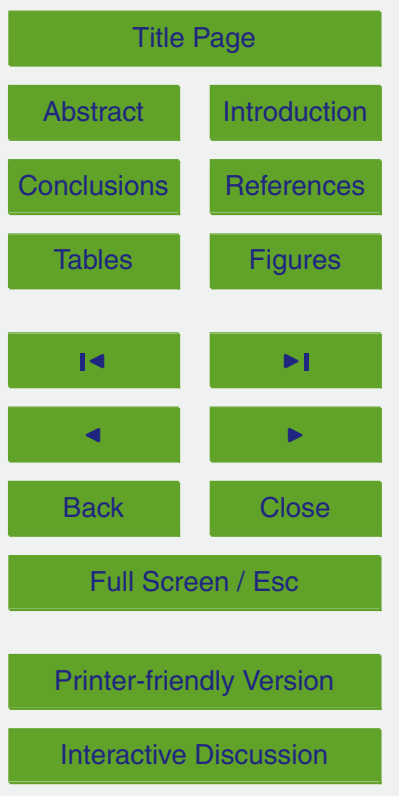


2011). Dirmeyer et al. (2004) revealed the large divergence of several model and remotely-sensed soil moisture datasets over these regions; at this time, most of the model-derived datasets relied on very simple, bucket-like hydrological schemes. Wagner et al. (2003) compared the ERS-derived soil moisture product (Scipal, 2003) to 5 global precipitation data and soil moisture modelled by the LPJ dynamic vegetation model: rather low to negative or insignificant correlations between these datasets were inferred over the circum-arctic regions, and the authors called for refinements of both the land-surface model and the soil moisture retrieval algorithm to address patent shortcomings for these regions. Similar low correlations were found over high-latitudes by 10 Naeimi et al. (2009b) between the ERA-Interim soil moisture dataset and ERS and MetOp-derived surface soil moisture, despite the use of an improved retrieval algorithm.

Meanwhile, the recognition of the potential climatic impact of circum-arctic regions (e.g. ACIA, 2005) and of the power of remote-sensing in this area of the globe have 15 spurred both model developments designed to address high-latitude processes (e.g. Gouttevin et al., 2012a; Wang et al., 2013) and efforts to improve the availability and capabilities of remote-sensing products over these regions (Bartsch et al., 2008, 2011; Högstrom et al., 2013). In this context, it may be time to investigate closely the remaining discrepancies between modelled and remotely-sensed soil moisture products over the circum-arctic regions, and derive guidelines for future developments.

Within the European Space Agency (ESA) DUE Permafrost project (Bartsch et al., 2012) several permafrost-related earth observation products were investigated and integrated, including a combined surface soil moisture and surface freeze-thaw status dataset (Paulik et al., 2012). The evaluation of this dataset is a constitutive part of the DUE Permafrost project and also an ongoing task as we write this manuscript (Heim et al., 2011). The surface freeze-thaw dataset was extensively validated through comparisons with in-situ data collected in diverse climatic regions including the high-latitudes, hence an assessed good accuracy for this product (Naeimi et al., 2012). The investigations carried out up to now regarding the surface soil moisture product reveal its
HESSD

10, 11241-11291, 2013

Remotely-sensed and modelled surface soil moisture at high latitudes

I. Gouttevin et al.

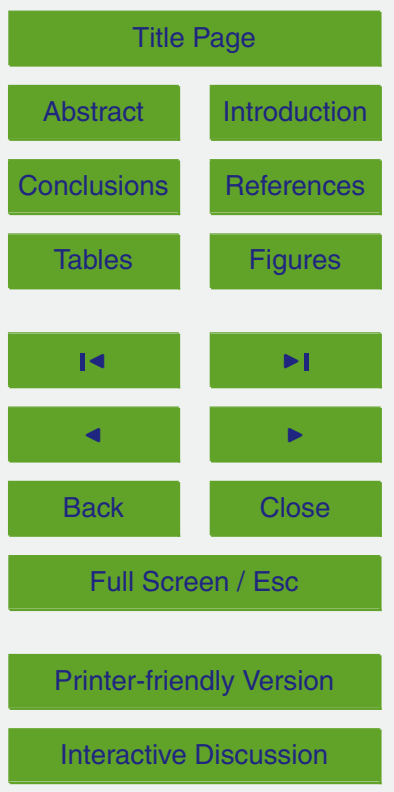


performance over permafrost landscapes pending necessary adjustments (Bartsch et al., 2009, 2011) which have now been integrated in the retrieval algorithm. This fuels our knowledge as to the accuracy and limitations of the ASCAT surface soil moisture dataset.

5 The present study intends to compare the DUE-Permafrost surface soil moisture and freeze-thaw products to relevant variables as modelled by the land-surface model ORCHIDEE, which includes a physically-based hydrological scheme refined for high-latitudes processes. It is part of the blended evaluation framework of the DUEPermafrost datasets, as the comparison of both products over a large continental do10 main may reveal previously unknown inconsistencies in the remote-sensing product, based on the known and different strengths of both products. This strategy is fully in line with the one adopted by previous cross-comparison studies (e.g. Wagner et al., 2003; Heim et al., 2011). Section 2.2 lists the plausible weaknesses of the surface soil moisture product that arose or were confirmed by our study. Here, these plausible inconsistencies of the remote-sensing dataset will be considered as such, and we will focus on the remaining model-to-data discrepancies, for which we derive likely modelling flaws. Parallel investigations are ongoing to determine to which extent these discrepancies could also or in part proceed from issues in the satellite product (Högstrom et al., 2013), but are beyond the scope of our study.

The first section of this article details the characteristics of the compared datasets and clarifies the methodological framework of the comparison. The comparison results are then displayed and analysed successively for surface status and soil moisture (Sect. 3). In the end, we formulate hypotheses as to the model-to-data discrepancies and suggest strategies to overcome them.
HESSD

10, 11241-11291, 2013

Remotely-sensed and modelled surface soil moisture at high latitudes

I. Gouttevin et al.

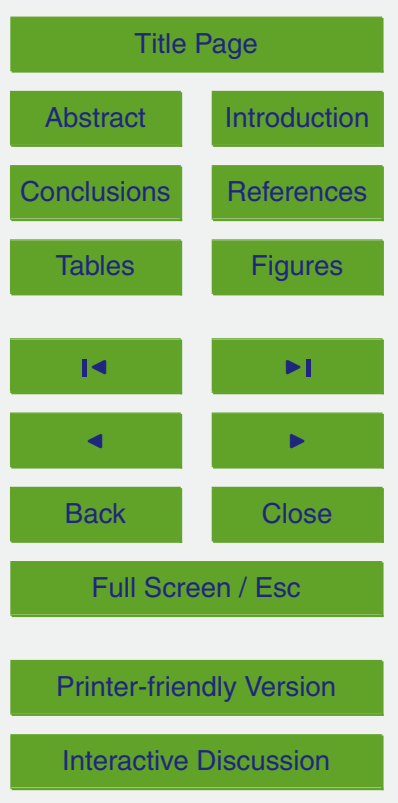




\section{Data, model and methods}

\subsection{Study area}

Our study area is the Siberian circumpolar region between the $30^{\circ} \mathrm{E}$ and $180^{\circ} \mathrm{E}$ meridians, and beyond $45^{\circ} \mathrm{N}$ (Fig. 1). It encompasses three of the four major drainage 5 basins of the Arctic (Lena, Yenissei and Ob) (Serreze et al., 2003) and the greatest part of the Northern Hemisphere land surface area subject to seasonal freezing or permafrost conditions (Zhang et al., 2008). Sub-regions of the study area have furthermore been the focus of investigations carried out within the DUE-permafrost or the related ALANIS-methane projects, and designed to complement our understanding of the capabilities and limitations of remote-sensing at these latitudes (e.g. Bartsch et al., 2012).

\subsection{Remote-sensing data}

The ASCAT (Advanced SCATterometer) instrument onboard the Meteorological Operation (MetOp)-A satellite is an active microwave sensor operating in C-band ( $5.3 \mathrm{GHz})$, a low frequency in the microwave domain suitable for soil moisture and surface status retrieval due to its ability to penetrate vegetation and to the sharp contrast of dielectric constant from dry or frozen to wet soil or melting snow at this frequency (Ulaby et al., 1982). This contrast is the theoretical basis for the remote sensing of soil moisture and surface status. Microwave frequencies are unimpeded by cloud cover, and active sensing allows acquisition during day and night. MetOp orbit and ASCAT instrument characteristics provide $80 \%$ global daily coverage at 25 and $50 \mathrm{~km}$ resolutions.

In this study, we make use of two complementary datasets derived from ASCAT time-series at $25 \mathrm{~km}$ resolution: the ASCAT Surface Soil Moisture (SSM) product and the ASCAT Freeze-Thaw (or Surface State Flag, hereafter SSF) product (Paulik et al., 2012). Details and quality assessment regarding both datasets can be found in Bartalis et al. (2007) and Naeimi et al. (2009b, 2012).

Remotely-sensed and modelled surface soil moisture at high latitudes

I. Gouttevin et al.

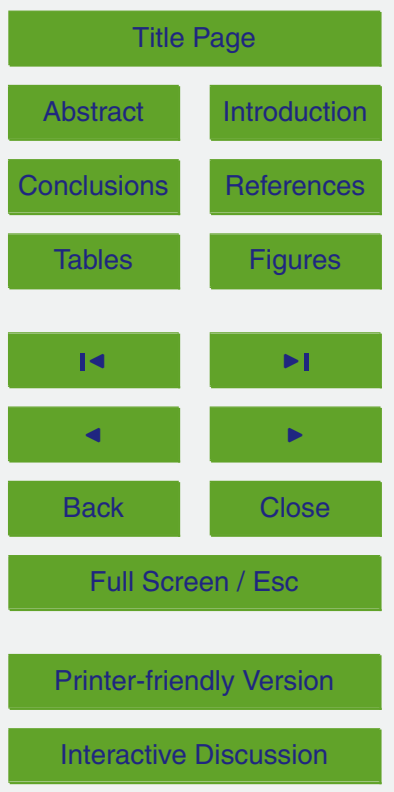

11249 
The surface soil moisture retrieval algorithm was developed at the Vienna University of Technology (TU Wien) based on a change detection method (Wagner et al., 1999, Naeimi et al., 2009b); WARP5.2 is the version of the algorithm used to produce the afore-mentioned SSM dataset. In this algorithm, components of the backscattered 5 microwave signal showing seasonal or lower-than-seasonal frequency variations are successively subtracted from the original signal. These components include surface roughness (assumed to be temporally invariant), vegetation canopy and vegetation water content (assumed to vary within several days to weeks). The residual signal then relates to the uppermost soil moisture content, which ranges from 1 to $5 \mathrm{~cm}$ depth de10 pending on surface state and soil water content. The ASCAT SSM product is masked out for frozen ground and snow-covered conditions based on the ASCAT SSF product (see below) and MODIS snow-cover data (Hall et al., 2010) respectively, as the soil moisture retrieval is not possible due to extremely low backscatter in such conditions. After incidence angle normalization, the backscattered signal is scaled between the

lowest (dry, 0\%) and highest (wet, 100\%) ever observed backscatter measurements considering of the historical time series of the ESR and MetOp observations; these observations date back to 1991 . This relative soil moisture index is then provided as a weekly composite of the indices computed on the day of interest and the preceding 6 days: a quality flag indicates the portion of measurements used for the 7-day composite with respect to maximal possible acquisitions.

The TU Wien Freeze-Thaw retrieval algorithm was used to create the ASCAT SSF dataset. This algorithm distinguishes between regions where the backscatter coefficient is higher in winter than in summer (due to higher liquid precipitation in winter, leading to wetter soils) and opposite (due to frozen surface having a generally lower backscatter than moderately wet soils). Distinct decision trees are applied in both regions, based on locally calibrated backscatter thresholds for freeze-thaw transition and snow melt. The final SSF product describes the surface status as frozen, unfrozen, melting snow or unknown.
HESSD

10, 11241-11291, 2013

Remotely-sensed and modelled surface soil moisture at high latitudes

I. Gouttevin et al.

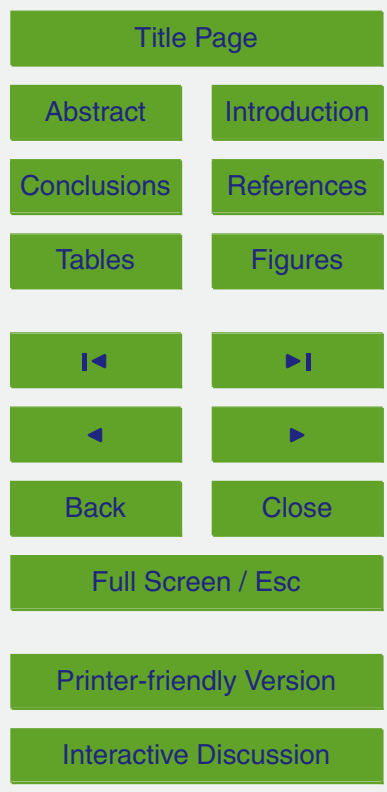


There are known limitations to both datasets affecting their accuracy over our study area.

Concerns have been raised as to the accuracy of the ASCAT SSF products in the area North of the Caspian and Black Seas; this issue is currently under investigation.

5 As we focus on the high latitudes we exclude these regions from our analysis and mask them out.

The TU Wien soil moisture and surface status retrieval algorithms fail over specific topography and land-cover types (complex topography, water bodies, dense vegetation, permanent ice or snow cover, coastal areas, deserts, and urban areas). Some of 10 these elements, in conjunction with the parameters of the algorithms, are used to estimate a combined measurement noise reflecting the quality of both products (Naeimi et al., 2009b). Based on a noise-threshold criterion (noise higher than $14 \%$ ), we exclude from our analysis the areas of identified algorithm failures and mask them out on the figures. Still, further limitations of the ASCAT SSM and SSF products are plausible; 15 some of them arose as a result from the present study (Bartsch et al., 2011). First, soil freezing or snow cover result in very low remotely-sensed surface soil moisture if not properly masked out. Secondly, permanently wet conditions as observed in some higharctic tundra environments are known to bias the dry reference computed by the SSM retrieval algorithm. In the ASCAT SSM product used for this study a dry correction for this bias is applied (Bartsch et al., 2011). A high fraction of open water surfaces was shown to have a minor impact on the retrieved SSM (Wismar et al., 2011); however the seasonal change in extent and/or status (lake ice) of open water areas may affect the temporal dynamics of the retrieved ASCAT SSM in a way that is not yet quantified (Högström et al., 2013). The accuracy of the ASCAT SSM product in areas with shallow or no soils may also be questionable. These known or potential limitations will be recalled when relevant on the course of our analysis.
HESSD

10, 11241-11291, 2013

Remotely-sensed and modelled surface soil moisture at high latitudes

I. Gouttevin et al.

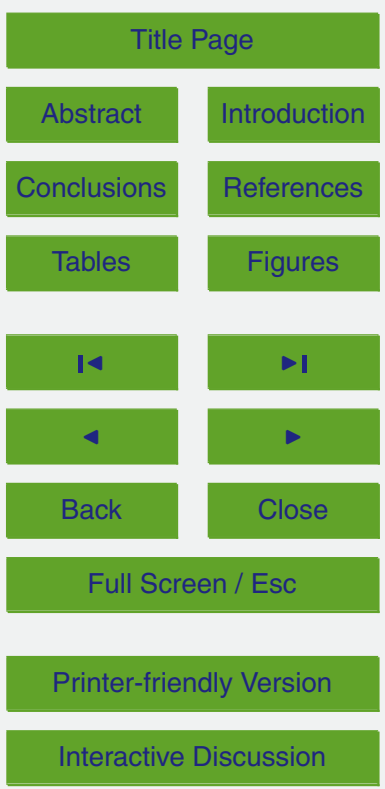




\subsection{Land-surface model}

The land surface model ORCHIDEE includes a soil moisture scheme computing water infiltration and vertical water diffusion within the soil based on the Richards' equation and a Van-Genuchten parameterization for matric potential and hydraulic conductivity. 5 Hydraulic parameters are derived from the Zobler (1986) soil textural map of the world brought down to three soil classes (coarse, medium and fine) and the respective hydraulic parameters by Carsel and Parrish (1988). Surface water that does not infiltrate nor evaporate is routed as surface runoff towards the rivers, while no lateral flow is accounted for below the ground surface. Vertical water diffusion occurs over the uppermost $2 \mathrm{~m}$ of the soil, where the impact of soil compaction and soil freezing on the hydraulic parameters are also accounted for, as well as water uptake by roots. At $2 \mathrm{~m}$ depth, if the soil is not frozen, soil water is considered to undergo free drainage: this drainage water is routed towards the rivers at a slower speed than surface runoff water. At the soil surface, the amount of infiltrable water is computed as a result of precipitation and evaporation. A thorough description of the soil moisture scheme can be found in De Rosnay (1999) and Gouttevin et al. (2012). In terms of soil moisture, the model output is a vertically-discretized volumetric soil moisture content. When the soil temperature drops below $0{ }^{\circ} \mathrm{C}$, part or all of the soil water freezes; the frozen fraction of the uppermost $5 \mathrm{~cm}$ of soil will be referred to as the modelled frozen fraction in the following. All model outputs are averaged at a daily resolution.

To model the hydrological dynamics of our study area over 2007-2009, we forced ORCHIDEE with a $2^{\circ} \times 2^{\circ}$ CRU-NCEP blended meteorological forcing (Viovy and Ciais, 2012). This forcing combines the CRU-TS2.1 (Mitchell and Jones, 2005) monthly climatology with the NCEP reanalyses starting from 1948 (Kalnay et al., 1996; Saha et al., 2010). A $10 \mathrm{yr}$ simulation was performed over 1997-2006 for the model to reach thermal and hydrological equilibrium; then the 2007-2009 simulation was performed for the purpose of our analysis.
HESSD

10, 11241-11291, 2013

Remotely-sensed and modelled surface soil moisture at high latitudes

I. Gouttevin et al.

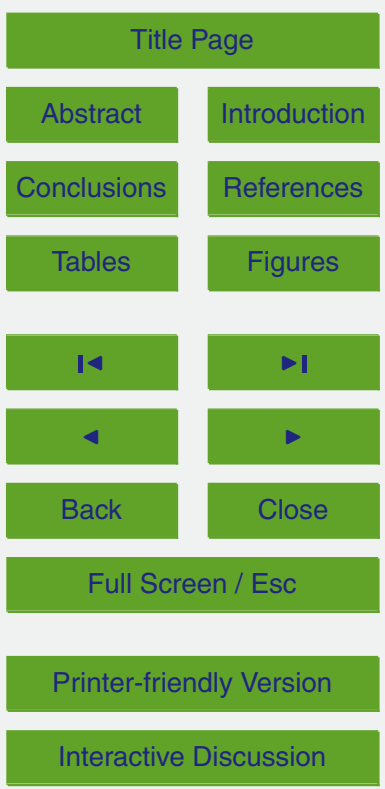




\subsection{Methods}

Concerning surface status, we chose to compare the modelled and remotely-sensed timing of end-of-spring final surface thaw as this timing is relevant to many climatological and ecological applications (e.g. Oberbauer et al., 1998; Koven et al., 2009). Yet, a 5 formal definition of this final day of thaw is necessary because at high latitudes, there is no unique day of thaw in the year: after snow melt or in early winter, the soil is affected by several freeze-thaw events induced by cold spells or just the diurnal air temperature cycle. These sporadic events do not correspond to a final end-of-winter surface thaw. Therefore, we here define the final day of thaw (referred to as "day-of-thaw" in the following) as the last day of the first half of the year when a soil-thawing/snow-melting event occurs and is preceded by at least a week of frozen-ground or snow-covered conditions. A similar definition was adopted to quantify the day of final autumn freezeback, however no analysis of modelled and remotely-sensed days of freezeback will be displayed here as conclusions are very similar to the day-of-thaw analysis.

The ASCAT SSF product we used relies for each pixel on all daily available backscatter measurements from MetOp ascending, descending passes and overlapping orbits. These measurements were made during two acquisition windows between 9 a.m. and 2 p.m. and 4 p.m. and 9 p.m. local time, depending on the latitude. During seasonal transitions when daily thawing and refreezing can occur, thawing and refreezing are likely to occur during the acquisition time-windows as a result of solar energy input. For simplicity, we will assume in the following that the solar energy input has an effect on the soil surface from 9 a.m. to 9 p.m., an approximation which has a physical meaning given the soil thermal inertia. Therefore, a pixel sensed as frozen by ASCAT during these acquisition windows is likely to be frozen more than $50 \%$ of the day, whereas a pixel sensed as unfrozen by ASCAT does not tell much about the portion of the day with prevailing frozen and unfrozen conditions.

Our model outputs are daily averaged frozen fractions. A $50 \%$ frozen fraction may be representative of frozen status over night and unfrozen status over day, a situation
HESSD

10, 11241-11291, 2013

Remotely-sensed and modelled surface soil moisture at high latitudes

I. Gouttevin et al.

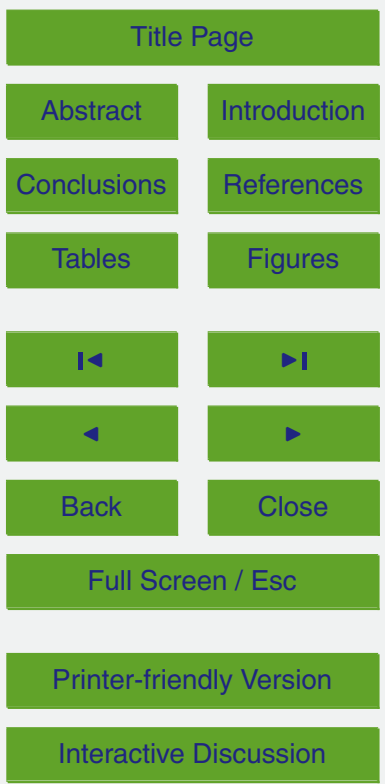


which ASCAT would systematically detect as unfrozen. Another threshold is reached when the soil surface reaches a completely unfrozen status only for a very brief fraction of the day. In this case, assuming a linear evolution of the frozen fraction during daytime (from 1 to 0 between 9 a.m. and 3 p.m., and from 0 to 1 between 3 p.m. and 9 p.m.), 5 the mean daily modelled frozen fraction is $75 \%$. For frozen fractions just below this threshold, unfrozen statuses can be detected by ASCAT, concomitantly with frozen statuses until the modelled frozen fraction reaches the $50 \%$ threshold.

To compare model outputs and ASCAT SSF data, using the $50 \%$ modelled frozen fraction as the threshold between frozen and unfrozen statuses would lead to overesti10 mate the occurrence of frozen situations in the model with respect to ASCAT detection, whereas the use of the $75 \%$ threshold would lead to underestimate them. We therefore chose a $62.5=(50+75) / 2 \%$ frozen fraction as threshold between frozen (frozen fraction over $62.5 \%$ ) and unfrozen (frozen fraction less than $62.5 \%$ ) conditions in the model for comparability with the ASCAT data. The sensitivity of our comparison results 15 to this threshold will be investigated in Sect. 3.

Regarding surface soil moisture, the model produces a volumetric soil moisture for each layer of the soil vertical discretization; the uppermost $5 \mathrm{~cm}$ of the soil consist out of the 5 uppermost soil layers (Gouttevin et al., 2012). The remotely-sensed SSM is a percentage-index resulting from the linear scaling of the retrieved backscatter (filtered reference. Depending on the water content, it relates to the uppermost $5 \mathrm{~cm}$ (low water content) or less (high water content) of the soil. It is produced as a weekly composite.

To be able to compare the modelled soil moisture output with ASCAT SSM data, we applied the following operations on the average volumetric soil moisture produced by the model for the uppermost $5 \mathrm{~cm}$ of the soil:

i. mask out for frozen ground conditions and snow-cover.
HESSD

$10,11241-11291,2013$

Remotely-sensed and modelled surface soil moisture at high latitudes

I. Gouttevin et al.

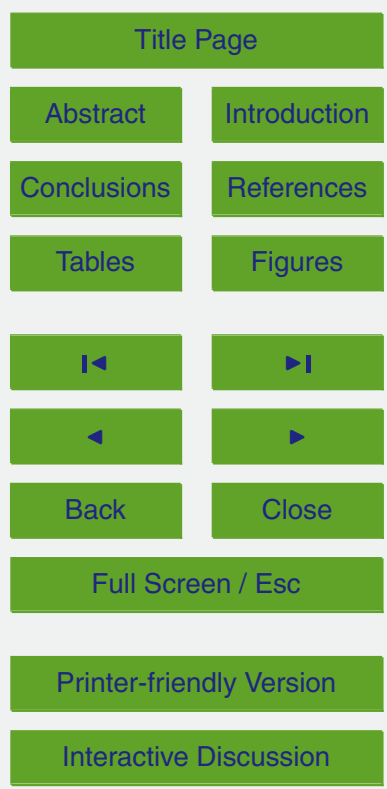


ii. for each model grid cell, identify the local historical wet and dry references and rescale the moisture content of step (i) on a $0 \%-100 \%$ scale. For this identification, the 1999-2009 period was used.

iii. produce a 7-day composite of the model output from step (ii).

5 The result of operation (iii) will be referred to in the following as the modelled SSM, standing for modelled surface soil moisture index.

When evaluating quantities involving both ASCAT and model SSM (e.g. correlation coefficients, common masking), spatial scaling issues are raised. For such comparisons the ASCAT SSM is averaged over the model grid-cells if a 'sufficient' number of observations within the model grid-cell are available; otherwise the area of the model grid-cell is masked. Our sufficiency-criterion is that more than $50 \%$ of the ASCAT pixels comprised within a model grid-cell contain a reliable SSM information.

\section{Results}

\subsection{Freeze-thaw timings}

15 Figure 2 compares the modelled and remotely-sensed timing of surface thaw for the year 2007; the percentage of agreement between remotely-sensed and modelled statuses over the study area is stated in Table 1.

Overall, the spatial pattern of the timing of remotely-sensed and modelled soil thaw compare well, with a complete surface thawing occurring last in the North-Western and Eastern parts of Siberia, due to persistent snow-cover for the former area and long enduring cold air temperature for the latter area. The mean standard deviation between the remotely-sensed and modelled timings of soil thaw is 19 days, but $57 \%$ of the study area features a remotely-sensed timing of end-of-season soil thaw within the $[50 \%-75 \%]$ range of modelled frozen fraction highlighted as relevant comparison thresholds in Sect. 2. The use of information on ASCAT acquisition times combined with

Remotely-sensed and modelled surface soil moisture at high latitudes

I. Gouttevin et al.

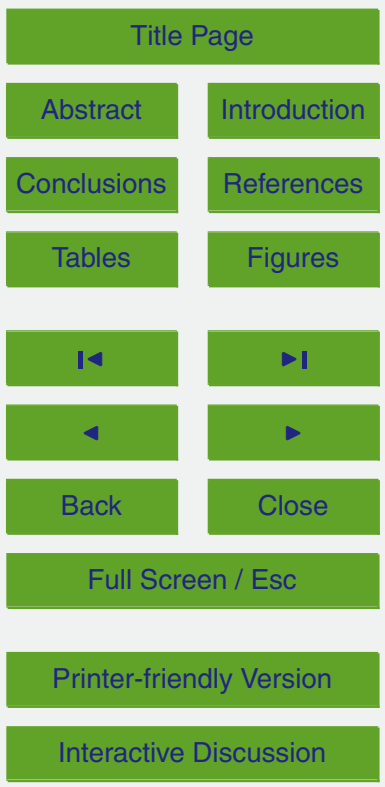


sub-daily model outputs could help refine the comparison thresholds and accuracy; however the former information was not provided within the ASCAT DUE-Permafrost product. The average model bias is towards a delayed surface thaw when compared to observations, which is reflected in the high agreement between modelled and observed 5 frozen statuses in winter and during the transition periods (spring and fall ; Table 1). This agreement is lower for unfrozen statuses: the model proves unable to represent conditions departing from the seasonal references, like summer freezing events or winter thawed surfaces. The reasons for that will be analysed in the following.

Two main types of model-to-data discrepancies can be identified: with respect to 10 ASCAT data, the modelled surface soil thaw occurs too late over North-Western and Central Siberia; contrarily, it occurs too early over the few unmasked relief areas like the Altaï range.

Surface soil thaw is closely related to the surface energy balance, which in the model can be biased by an inaccurate atmospheric forcing or intrinsic modelling flaws pertaining to the representation of surface conditions and fluxes. In springtime, the surface energy balance is especially sensitive to the occurrence and amount of snow: the high albedo of snow reflects solar incoming radiations while snowmelt is a significant energy sink. A comparison of modelling results with the monthly averaged CMC snow water equivalent (SWE) data (Brown et al., 2010) for April 2007 revealed a clear overestimation of the modelled SWE over North-Western and part of North-Central Siberia, with exception of the Putorana Plateau. Contoured on Fig. $2 \mathrm{~b}$ are the areas where the model overestimates (resp. underestimates) the April 2007 SWE by more than $20 \mathrm{~mm}$ with respect to CMC data. Based on this comparison, we inferred that $50 \%$ of the areas where the modelled timing of thaw is delayed when compared to ASCAT data also exhibit an overestimation of the April SWE. Conversely, $43 \%$ of the regions with an early modelled soil thaw with respect to ASCAT data also display an April SWE deficit; only $8 \%$ of them have a snow overestimation over $20 \mathrm{~mm}$ SWE. Part of the delay (resp. advance) of the modelled timing of surface thaw can therefore be attributed to the misrepresentation of snow.
HESSD

10, 11241-11291, 2013

Remotely-sensed and modelled surface soil moisture at high latitudes

I. Gouttevin et al.

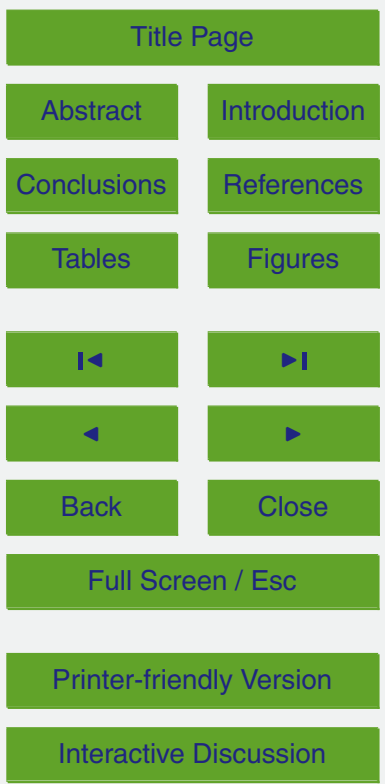


The former case is illustrated in Fig. 3a at location 1 with coordinates $80^{\circ} \mathrm{E}, 67^{\circ} \mathrm{N}$ North-West of the Putorana Plateau (this location, along with locations 2 and 3 , is identified on Fig. 2). There, the remotely-sensed timing of melt coincides with an atmospheric air temperature signal crossing the freezing point, but the delayed model soil 5 response originates from a longer than observed snowmelt period. At this location, the model overestimates the April SWE by $85 \mathrm{~mm}$ (e.g. $\sim 25 \mathrm{~cm}$ snow depth assuming a snow density of $300 \mathrm{~kg} \mathrm{~m}^{-3}$ ) with respect to $\mathrm{CMC}$ data.

There is much uncertainty in the solid precipitation accounted for in the atmospheric forcing datasets and especially over Siberia, as a result of the lower density of meteo10 rological stations there and the necessity of applying corrections for gauge undercatch (e.g. Sheffield et al., 2006; Weedon et al., 2011; Burke et al., 2013). The possibility of an overestimation of solid precipitation in the forcing data cannot be ruled out, resulting in an overestimated snow water equivalent in the model and a longer-than-observed modelled melting period. The atmospheric forcing we used in this study relies on NCEP 15 reanalyses corrected by the $\mathrm{CRU}$ precipitation dataset. Other precipitation datasets like the GPCC dataset (Global Precipitation Climatology Centre; http://gpcc.dwd.de; Fuchs et al., 2009) display a denser observational network at high latitudes. The WATCH forcing dataset (Weedon et al., 2011) makes use of GPCC data for precipitation corrections. However, ancillary simulations performed with the WATCH atmospheric forcing over the study area revealed similar SWE overestimation (resp. underestimation) patterns for the year 2007 with respect to CMC data.

Another bias towards a delayed snowmelt may originate from the snow albedo parameterization currently in use in the model ORCHIDEE (Chalita, 1992), which does not account for the substantial decay of the snow albedo during the melting period.

Also, the parameterization of snow albedo decay with time over vegetated areas needs revision (Gouttevin, 2012) and may explain the delayed timing of surface thaw over the forested areas of Central Siberia. A new snow scheme is currently under development (Wang et al., 2013) but has not been used for this study as it not yet adapted to forested areas.
HESSD

$10,11241-11291,2013$

Remotely-sensed and modelled surface soil moisture at high latitudes

I. Gouttevin et al.

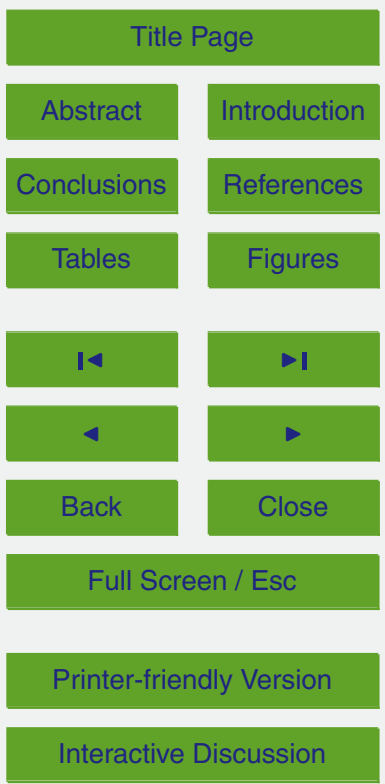


Additional flaws in the atmospheric forcing can not be ruled out, as illustrated at location 2 in Central Siberia $\left(120^{\circ} \mathrm{E}, 67^{\circ} \mathrm{N}\right.$, Fig. 3b). In this region, the atmospheric forcing does not allow simulating the remotely-sensed timing of soil thaw, which occurs at the end of April. In the atmospheric forcing, air temperatures cross the freezing point only in May and almost continuous snowfall occur until mid-May.

Over unmasked relief areas (Putorana, Altaï and Baikal ranges), remotely-sensed data indicate a very late final surface thaw which is not captured by the model (Location 3 at $99.5^{\circ} \mathrm{E}, 53^{\circ} \mathrm{N}$, Fig. 3c). In those middle-to-high altitude areas, freeze-thaw and snowfall events are frequent even in summer. Such events are not featured by the 10 atmospheric forcing, probably due to its low spatial resolution that does not allow resolving relief areas accurately. North-Eastern relief areas are also likely subject to solid precipitation underestimation in the forcing data (Fig. 2b).

To conclude, identified inconsistencies between the atmospheric forcing and remotely-sensed data, especially over high-latitudes and high-altitude areas, reduce the model's ability to capture the exact timing of surface soil thaw. Known model biases can also contribute to these moderate performances. The overall reasonable agreement between modelled and remotely-sensed timing of end-of-season soil thaw (and early season freeze-back, not developed here) ensures that surface liquid soil moisture data and model outputs will be compared in the following over periods of similar extent.

\subsection{Surface soil moisture}

\subsubsection{Mean spatial patterns}

The annually-averaged pattern of surface soil moisture derived from satellite data is stable over the three years of available data and illustrated by Fig. 4a. High mean surface moisture indeces are retrieved for the flat and low-altitude domains of our study area, with highest values in the Western Siberian Lowlands, over Arctic coastal areas, and the Taymyr Peninsula. This is consistent with known hydro-climatologic features of the Siberian Arctic drainage system: the Western Siberian Lowlands receive important

\section{HESSD}

10, 11241-11291, 2013

Remotely-sensed and modelled surface soil moisture at high latitudes

I. Gouttevin et al.

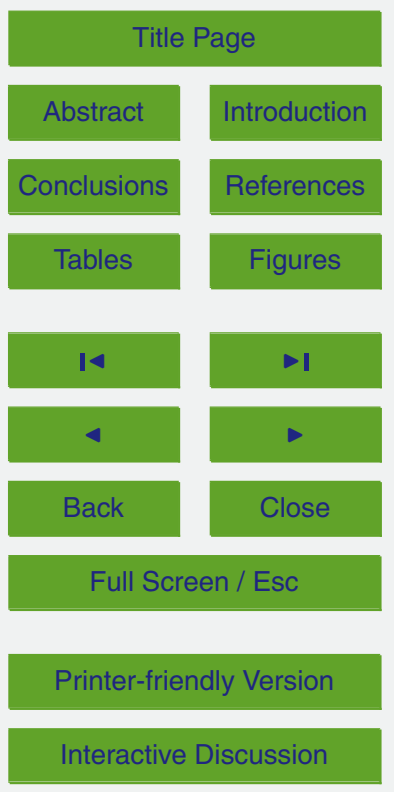


amounts of precipitation and host large floodplains and ponding areas in spring and summer (e.g. Serreze et al., 2003); the Arctic coastal plains exhibit typical wet tundra landscapes where saturated conditions can locally prevail (e.g. Boike et al., 2008); the Taymyr Peninsula counts among the regions with the shortest snow-free season in the

5 Siberian Arctic. This, combined with cold summer air temperature, shallow active layer (annual superficial thaw depth of permafrost) and low and poor vegetation, creates conditions favourable to ponding (Boike et al., 1998).

Conversely, the few unmasked relief areas (Ural range, Putorana, Baikal and to some extent, Altaï ranges) exhibit lower mean surface soil moisture indeces. This observation 10 is consistent with the rapid response of mountain watersheds to precipitation events and efficient drainage and routing of surface runoff resulting from slope, limited vegetation cover and ground structure (rocky features, shallow soils). Consistently, mountainous regions also tend to exhibit high standard deviation values for SSM (Fig. 5a).

However, the reliability of the ASCAT soil moisture product is lower in these regions 15 and relatively high noise (though lower than $14 \%$; Sect. 2) can pollute the signal and artificially enhance the standard deviation of SSM. Concerns have been raised as to the accuracy of soil moisture retrieval in areas with very shallow soils: this feature is common below complex topography. Additionally, the yearly number of valid soil moisture measurements is low in mountainous areas because of frequent freezing and snowfall conditions all year long (Appendix, Fig. A1). Failure at masking out the ASCAT SSM products for such conditions result in an underestimation of the soil moisture index inferred from remote-sensing due to low backscatter. The impact of these failures on the ASCAT mean SSM and standard deviation is increased by the short duration of the period when measurements are possible.

The northernmost Siberian coastal areas and especially northernmost Taymyr are other regions of high uncertainty in the ASCAT SSM data: persistently wet conditions and water bodies introduce a bias in the dry reference determination, which is artificially corrected for (Bartsch et al., 2011). Possibly, seasonal changes in the extent of water
HESSD

$10,11241-11291,2013$

Remotely-sensed and modelled surface soil moisture at high latitudes

I. Gouttevin et al.

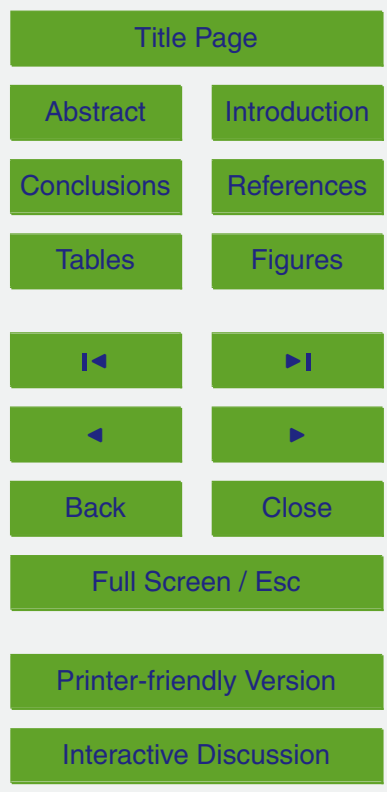


bodies also require a correction. Research is currently ongoing to quantify these effects (Högström et al., 2012), and these regions will therefore be left out of our analysis.

The mean modelled SSM spatial patterns do not match well the mean remotelysensed SSM spatial patterns (Fig. 4b).

$5 \quad$ In areas with low relief, the model tends to exhibit lower surface soil moisture indices than derived from the ASCAT sensor: this difference is very pronounced in Western Siberia and of lower magnitude in Eastern Siberia. Both situations are illustrated in Appendix in Fig. A2 over two $1^{\circ} \times 1^{\circ}$ regions marked on Fig. 4 (locations 4 and 5). As model outputs and ASCAT data were subject to comparable rescaling, temporal 10 averaging and masking out procedures (Sect. 2), lower modelled SSM values can be indicative of quicker surface soil drying: the plausibility of this process and other possible causes of this discrepancy will be discussed later in this section and in Sect. 4.

On the opposite, the highest modelled SSM values are computed over mountain ranges (Central Siberian Plateau, Verkhoyansk, Tcherski, Kolyma and Altaï ranges), 15 relief areas which receive more precipitation in the forcing data while colder air temperatures drive lower evaporative fluxes. This is a discrepancy from observational data for the few mountainous areas where ASCAT SSM data are available (Central Siberian Plateau, Altaï). It may be symptomatic of the absence of a specific representation of mountainous areas in the hydrological scheme of the land-surface model: none of the three soil texture classes and associated hydraulic parameters used by the model is designed to represent mountainous terrains and the quick drainage or water routing associated to them. Furthermore, the only effect of slope accounted for in the model is a reduction in surface runoff reinfiltration at the grid-cell scale, while there is no limitation of direct infiltration. This situation is illustrated at location 6 in the Central Siberian Plateau (Fig. A2c): the model is not able to reproduce the extent of the observed midJuly soil moisture depletion. Soil freezing or snow-covered events responsible for the absence of ASCAT SSM data for a short period in mid-July are also not captured by the model. Finally, the June low ASCAT SSM may be induced by failures of the AS-
HESSD

$10,11241-11291,2013$

Remotely-sensed and modelled surface soil moisture at high latitudes

I. Gouttevin et al.

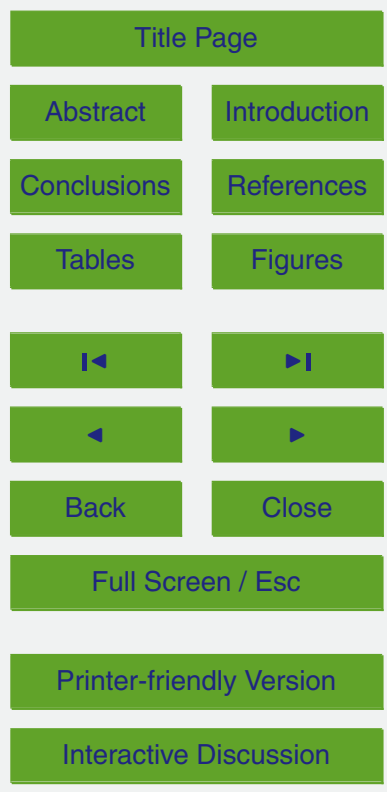


CAT masking for snow-cover or frozen ground conditions, enhancing the model-to-data divergence.

Consistently with observational data, the modelled SSM exhibit the highest standard deviations over the Western Siberian Lowland to the East of the Ob river and over relief

5 areas, as a result of frequent heavy rainfall events (Fig. A2a and c). In accordance with model and data shortcomings mentioned above, the modelled standard deviations are mostly of lower magnitude than recorded by observations in mountainous areas.

The behaviour differences between model outputs and remotely-sensed signals pointed out in this section lead to a low model efficiency in the sense of Nash and 10 Sutcliff (1970), with a mean efficiency criterion of -4.4 over the study area.

\subsubsection{Daily correlations}

The modelled and remotely-sensed SSM exhibit spatially variable correlation at the daily timescale (Fig. 6). Correlation is distinctively high in Western Siberian regions and low in North-Eastern Siberian regions, with contrasted results over the unmasked mountainous areas. In each case, the modelled SSM responds closely and consistently to precipitation events reported by the forcing data (Fig. A2; in this figure the modelled unscaled SSM is the real-time modelled saturation degree of the uppermost $5 \mathrm{~cm}$ of soil, and reacts consistently to precipitation events occurring in the atmospheric forcing).

20 Two types of anti-correlation periods can be distinguished: periods with ASCAT SSM increasing while modelled SSM decreases, and the exact opposite. In terms of surface soil moisture, the former periods corresponds to undue surface drying in the model with respect to observations; the latter indicate undue surface moistening.

To characterize the dominant type of model error with respect to the observations, we computed the normalised difference between the number of days respectively showing undue surface moistening $\left(N_{\text {moist }}\right)$ and undue surface drying $\left(N_{\text {dry }}\right)$ in the model.

Remotely-sensed and modelled surface soil moisture at high latitudes

I. Gouttevin et al.

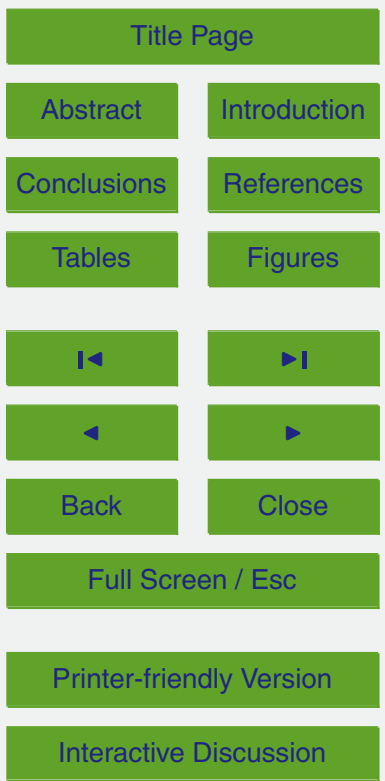


This normalized difference $N$ is calculated as follows, and illustrated in Fig. .

$N=\frac{N_{\text {moist }}-N_{\text {dry }}}{N_{\text {moist }}+N_{\text {dry }}}$

Undue surface drying can proceed from:

i. excessive modelled evaporation;

ii. too rapid a drainage of surface water towards the deeper soil;

iii. excessive modelled surface runoff due to a misrepresented partition between runoff and infiltration;

iv. underestimated or unrepresented precipitation events in the driving forcing data. This can also proceed from misrepresented phase of the precipitation, with solid precipitation leading to a delayed soil moistening.

Undue surface moistening results from opposite conditions.

In Fig. 7, mountainous areas mostly exhibit undue surface drying situations. In these areas, a positive bias in the modelled evaporation can not be excluded as the coarse resolution of the forcing data does not allow to represent the real temperature conditions at high altitude. It is however hard to assess the magnitude of this likely evaporation bias on the modelled surface soil moisture.

Excessive surface drainage towards the deep soil or a positively biased runoff to infiltration ratio are improbable given the absence of representation of the specific hydrological regime of mountainous areas in the model. Besides, the higher-than-observed mean modelled SSM in mountainous area (Fig. 4a) would then imply positively biased precipitation and/or negatively biased evaporation over those areas: the former is unlikely given the frequent presumption of underestimated precipitation over relief areas in low-resolution climate forcing data (e.g. Adam et al., 2006) and the snow bias identified in Sect. 3; the latter is inconsistent with the likely modelling bias mentioned above.

Remotely-sensed and modelled surface soil moisture at high latitudes

I. Gouttevin et al.

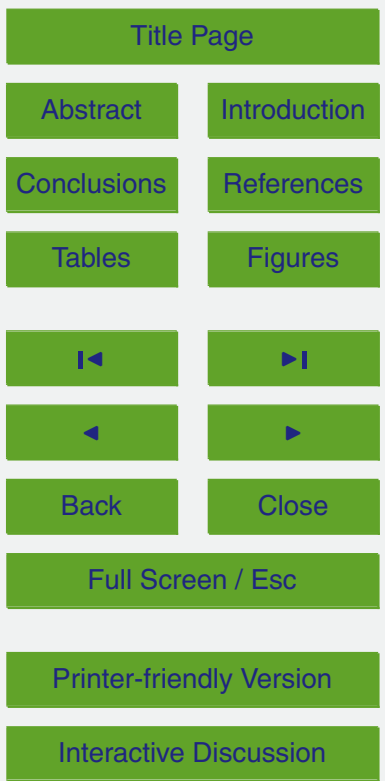


Most probably, the dominating undue surface drying situations over mountainous areas are thus induced by an underestimation or mis-represention (in terms of phase and occurence) of precipitation events: such a bias is consistent with the coarse resolution of the atmospheric forcing and existing scientific literature.

5 Over the regions of lower altitude with low daily correlations between remotelysensed and modelled SSM (e.g. Eastern part of the Central Siberian Plateau, NorthEastern Siberia), undue surface moistening is the dominant deviation of the model from observational data. In these areas, barren, rocky landscapes with low-altitude relief features are frequent (Fig. 1). The Eastern Central Siberian Plateau is character10 ized by leptosols, i.e. shallow soils overlying hard rock or very gravely or calcareous material (Jones et al., 2010). Such soils are characterized by rapid drainage, while relief features associated with sparse vegetation reduce water reinfiltration and enhance runoff. These effects are not represented in the model. This points to the opposite of mechanisms (ii) and (iii) as likely causes of the low performance of the hydrological model in those areas. Besides, the quality of ASCAT data can be questionable over such landforms (see above). The clear decrease in model performances over NorthEastern Siberia may also proceed from the extreme low density of the ground-based observational network in this region (e.g. Uppala et al., 2005), hampering the quality of the atmospheric forcing data especially precipitation (e.g. New et al., 1999; Hulme and New, 1997; Legates, 1988).

\subsubsection{Spatio-temporal variability}

We investigate the interannual variability of the modelled and remotely-sensed signals based on the mean SSM indices in the three main basins of our study area: Ob, lenissei and Lena (Fig. 8). In this figure, the spatial average of the SSM is weighted by the importance of signals related to areas of limited extent and of possibly different locations between the model and the data when the basins are still partially frozen.

HESSD

10, 11241-11291, 2013

Remotely-sensed and modelled surface soil moisture at high latitudes

I. Gouttevin et al.

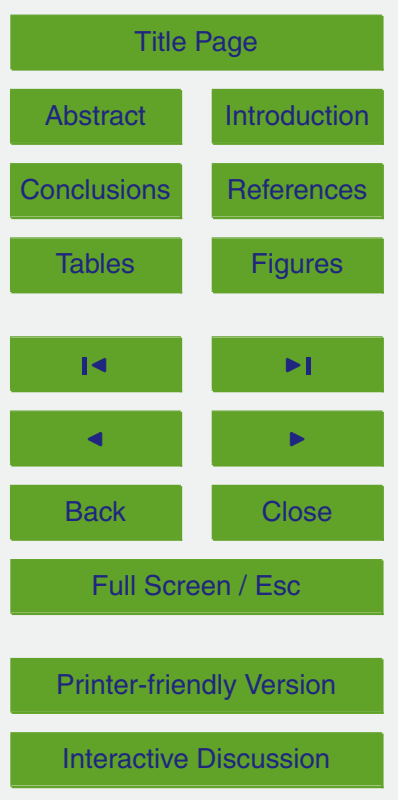

11263 
The model is able to follow the main seasonal and annual variations of the remotelysensed signal, though with lower performance on the Lena basin. Part of this agreement results from the good ability of the model to reproduce the seasonal extent of prevailing frozen ground conditions (Sect. 3.1). For almost all basins and years with 5 available data, the annual maximum of the basin-averaged surface soil moisture index is underestimated by the model, in line with a mean surface soil moisture index underestimation over most areas mentioned earlier. In the remotely-sensed data, this annual maximum occurs in late June or July, when a combination of processes leading to wet soils occur: snow-melt, surface soil thaw, early-summer precipitation falling on waterlogged soils, temporal flooding of large areas as a result of river bank overflow. This last feature is particularly pronounced in the Western Siberian Ob basin (e.g. Lehner and Döll, 2004; Ringeval et al., 2012). In most years and basins, the model is able to reproduce this late-spring peak in surface soil moisture, though with a lower-than-observed amplitude. In 2008 for the $\mathrm{Ob}$ and Lena basins, heavy late summer rainfall however lead to higher basin-scale modelled SSM than induced by late spring processes.

Zonal averages of the modelled and remotely-sensed SSM confirm these differences between both spatio-temporal patterns (Fig. 9). The dominant feature of the remotelysensed signal is the spring soil moisture increase, which covers all latitudinal bands above $60^{\circ} \mathrm{N}$ between June and July. This signal is only partially reproduced by the model in 2008 (when it spreads from $64^{\circ} \mathrm{N}$ to $68^{\circ} \mathrm{N}$ ) and 2009. Over all years, however, the dominant feature of the modelled signal is the SSM response to late summer precipitation.

\section{Discussion}

The hydrological module of ORCHIDEE shows a reduced ability to reproduce some dominant features of the hydrological regime of our study area: a marked late spring increase in surface soil moisture, prevailing over Western Siberia; and the overall drier surface status of mountainous soils. Several modelling shortcomings can be incrim-
HESSD

10, 11241-11291, 2013

Remotely-sensed and modelled surface soil moisture at high latitudes

I. Gouttevin et al.

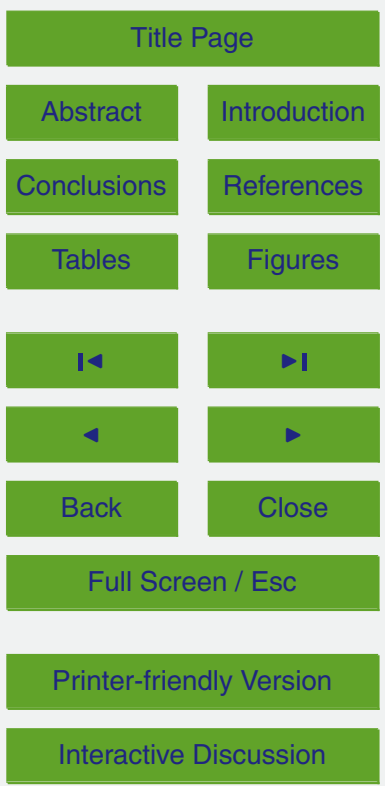


inated for these moderate performances; we synthesize them below and in Table 2, along with possible ways to circumvent them.

i. In the model, standing waters and the lateral redistribution of excess surface runoff within a grid cell are not accounted for. Instead, excess surface water is routed towards the rivers; no floodplains are accounted for in the version of the model used for this study. This shortens the duration of saturated surface conditions in the model and limits the model's ability to represent the spring surface soil moisture signal. In other versions of ORCHIDEE, modules representing floodplains and ponding water have been developed (Vivant, 2003; d'Orgeval, 2006); their use could improve the performance of our hydrological modelling in flat areas like the Western Siberian Lowlands.

ii. The hydrological module of ORCHIDEE theoretically allows different soil types to coexist over the same grid-cell: in this case, separate hydrological balances are computed for each soil type, representative of specific hydrological properties. However, the soil map used by ORCHIDEE (Sect. 2.3) exhibits a very limited spatial variability of soil types over the study area. Medium textured soils dominate, with coarse soils sporadically appearing in the Western Siberian Lowlands only. As stated in Sect. 3, this may be not representative of the hydrological properties of soils over large areas of our study domain, with Central and Eastern Siberian landscapes featuring large extents of rocky, or gravely, barren soils. Since the compilation of soil texture data into a five-classes map by Zobler (1986), there has been progress in soil science and knowledge even at high latitudes (e.g. Hugelius, 2012; Jones et al., 2010) and a revision of the soil maps and possibly parameters in use in ORCHIDEE is needed. The 12-classes soil textural map by Reynolds (1999) and associated soil hydrological parameters, for instance, distinguishes the specific soil types of the Western and Eastern Siberian regions and could improve our hydrological modelling there.

Remotely-sensed and modelled surface soil moisture at high latitudes

I. Gouttevin et al.

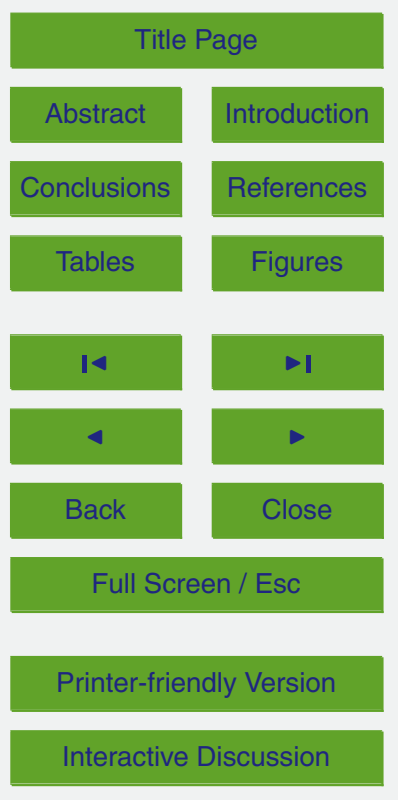


iii. This may not be enough to capture the specific hydrological regime of relief areas. Approaches to account for topography and soil water redistribution at the basins scale exist (e.g. Beven and Kirkby, 1979; Gedney and Cox, 2003) and have been recently implemented in ORCHIDEE (Ringeval et al., 2012), though not used in this study. In particular, they include a representation of Dunne runoff from precipitation falling over a saturated fraction of the model grid: some improvement of the model performances in areas of low and high relief could be induced by the use of these new developments.

The model-dependency and limited physical meaning of soil moisture computed by global climate models and land surface schemes have been recurrently underlined (e.g. Koster et al., 2009; Scipal et al., 2008). Though ORCHIDEE includes a physicallybased representation of soil moisture, our results suggest that the spatial resolution and the spatially-explicit soil parameters in use in this study, combined with the hydrological processes accounted for, still hamper the representation of a volumetric soil moisture content of entire physical meaning by the model.

This diagnostic of the model performances proceeds from several coherent lines of evidence and distinct identified regional patterns, hence its robustness. However, identified limitations of our methodological framework and of the satellite dataset can additionally contribute to the diagnosed model-to-data discrepancies:

i. In the WARP5 algorithm used to infer the remotely-sensed SSM from the original backscatter signal, the surface soil wet and dry references are computed as averages of maximum (resp. minimum) backscattered signals over a number of extreme events depending on the region and on the estimated uncertainty of the ASCAT SSM product for this region. Our methodology only relies on the absolute maximum and minimum modelled SSM over 1999-2009. Though this period is shorter than the 1991-2009 reference period of the WARP5 algorithm (Sect. 2), we suspect that our methodology overestimates (resp. underestimates) the wet (resp. dry) reference with respect to observational data, due to the absence of averaging over several extreme events. An overestimation of the wet reference in 11266

\section{HESSD}

10, 11241-11291, 2013

Remotely-sensed and modelled surface soil moisture at high latitudes

I. Gouttevin et al.

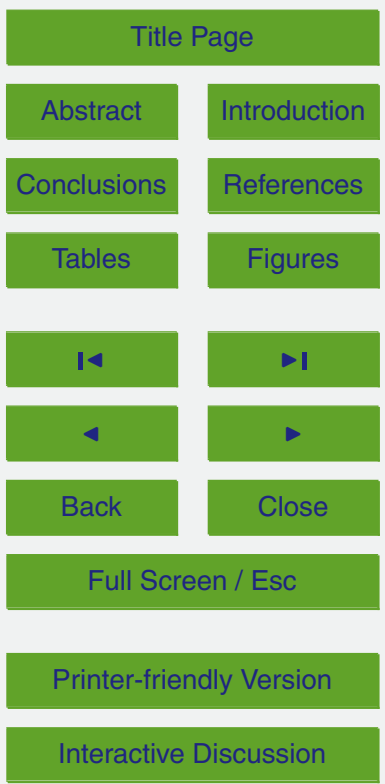


the model could explain the structurally lower-than-observed surface soil moisture modelled over most of our study area.

ii. The ASCAT SSM relates to a soil layer with thickness ranging from $5 \mathrm{~cm}$ to a few milimeters when the soil is saturated. We compared it to modelled SSM relating to a fixed uppermost soil thickness of $5 \mathrm{~cm}$, which may lead to soil moisture underestimation when only the uppermost soil is saturated.

iii. The ASCAT data have been shown prone to confound volume scattering by snow with scattering from wet soil (Sect. 3.2). Despite the masking out of the ASCAT products with ancillary snow data (Sect. 2), residual failures are still plausible, lowering the quality of the ASCAT SSM product especially on mountainous areas.

iv. Plausible limitations of the current ASCAT products are under investigation, in link with soil depth, types, and seasonal changes in land-cover related to lake ice and water bodies extent. Uncertainties related to them have so far not been quantified.

These issues are to be addressed in forthcoming studies.

Finally, our study points out substantial modelling limitations induced by the quality of the atmospheric forcing: the incorporation of remotely-sensed surface soil moisture and soil status data in the assimilation schemes providing reanalysis fields could offer an alternative to the scarcity of observational data over the remote areas of the panArctic region.

\section{Conclusions}

Despite known and plausible weaknesses of the satellite products at high latitudes, our model-to-data comparison allowed to highlight general strengths and limitations of hydrological modelling in ORCHIDEE over Northern Eurasia.

The ORCHIDEE land surface model shows a good ability to reproduce the observed spatial and seasonal pattern of ground freezing; potential improvement though lies in

Remotely-sensed and modelled surface soil moisture at high latitudes

I. Gouttevin et al.

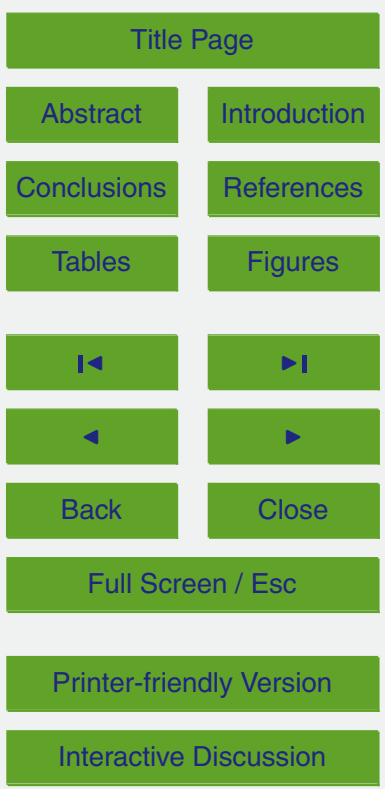


the snow-scheme, especially with respect to albedo modelling; developments in this direction are under way. The coarse resolution of our atmospheric forcing hampers the ability of the model to capture isolated freeze-thaw events and the exact timing of end-of-winter soil thaw over relief areas.

5 In terms of soil moisture, despite a consistent model response to precipitation events, the model recurrently diverges from observations. Relief areas tend to be wetter than observed, in spite of likely underestimation of the liquid precipitation in the forcing data. This paradox reflects a poor representation of the specific hydrological regime of mountainous regions in the model. Over flat areas, the model moderately correlates 10 with observations, probably because the ponding and river bank-overflow mechanisms leading to water-logged conditions are not represented. This is especially true in the Western Siberian Lowlands, and prevents the model from capturing the main seasonal dynamics of the uppermost soil moisture over our study area. Developments exist or are under way, which, along with the use of state-of-the-art soil maps and parameters, should improve our hydrological modelling over the pan-Arctic area.

Finally, the comparison of modelled remotely-sensed surface statuses and surface soil moisture indices highlighted inconsistencies in the atmospheric forcing data especially over relief areas and North-Eastern Siberia. This points towards possible benefits upon the integration these remote-sensing products in the elaboration of atmospheric forcing data.

Investigations are also currently underway to address remaining shortcomings in the satellite products at high latitudes; they will possibly help strengthen our conclusions in near future.

Acknowledgements. The authors thank Catherine Ottle for valuable advice on the manuscript and acknowledge financial support by the European Union FP7-ENV project PAGE21 under contract number GA282700.

\section{HESSD}

10, 11241-11291, 2013

Remotely-sensed and modelled surface soil moisture at high latitudes

I. Gouttevin et al.

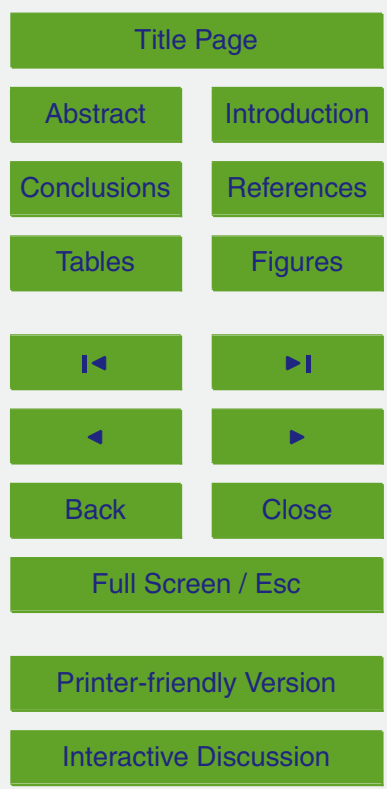


Remotely-sensed

and modelled surface

\section{References}

Adam, J., Clark, E., Lettenmaier, D., and Wood, E.: Correction of global precipitation products for orographic effects, J. Climate, 19, 15-38, 2006.

Bartalis, Z., Wagner, W., Naiemi, V., Hasenauer, S., Scipal, K., Bonekamp, H., Figa, J., and Anderson, C.: Initial soil moisture retrievals from the Metop-A Advanced Scatterometer, Geophys. Res. Lett., 34, L20401, doi:10.1029/2007GL031088, 2007.

Bartsch, A., Balzter, H., and George, C: The influence of regional surface soil moisture anomalies on forest fires in Siberia observed from satellites, Environ. Res. Lett., 4, 045021, doi:10.1088/1748-9326/4/4/045021, 2009.

Bartsch, A., Kumpula, T., Forbes, B. C., and Stammler, F.: Detection of snow surface thawing and refreezing in the Eurasian Arctic with QuikSCAT: implications for reindeer herding, Ecol. Appl., 20, 2246-2358, 2010.

Bartsch, A., Pathe, C., Wagner, W., and Scipal, K.: Detection of permanent open water surfaces in central Siberia with Envisat ASAR wide swath data with special emphasis on the estimation of methane fluxes from tundra wetlands, Hydrol. Res., 39, 89-100, 2008.

Bartsch, A., Sabel, D., Wagner, W., and Park, S.-E.: Considerations for derivation and use of soil moisture data from active microwave satellites at high latitudes, Proceedings of the Geoscience and Remote Sensing Symposium (IGARSS), 2011, IEEE International, Vancouver, Canada, 24-29 July 2011, 3132-3135, doi:10.1109/IGARSS.2011.6049882, 2011.

Bartsch, A., Trofaier, A. M., Hayman, G., Sabel, D., Schlaffer, S., Clark, D. B., and Blyth, E.: Detection of open water dynamics with ENVISAT ASAR in support of land surface modelling at high latitudes, Biogeosciences, 9, 703-714, doi:10.5194/bg-9-703-2012, 2012.

Betts, A. K. and Ball, J. H.: Albedo over the boreal forest, J. Geophys. Res., 102, 28901-28909, 1997.

soil moisture at high

latitudes

I. Gouttevin et al.

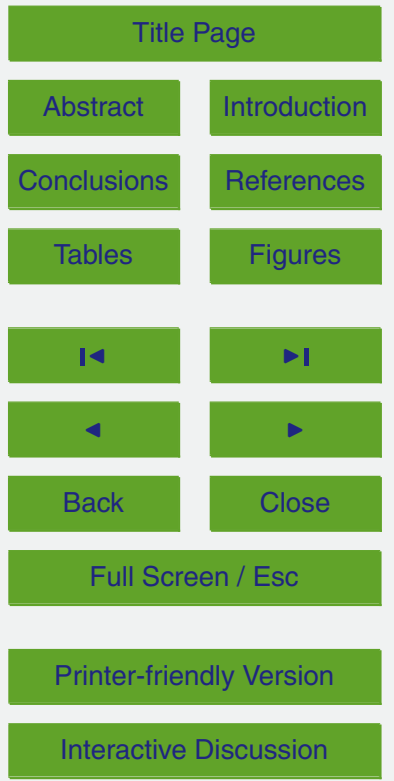


Beven, K. and Kirkby, M.: A physically based, variable contributing area model of basin hydrology, Hydrolog. Sci. J., Taylor and Francis, 24, 43-69, 1979.

Boike, J., Roth, K., and Overduin, P. P.: Thermal and hydrologic dynamics of the active layer at a continuous permafrost site (Taymyr Peninsula, Siberia), Water Resour. Res., 34, 355-363, 51998.

Boike, J., Wille, C., and Abnizova, A.: Climatology and summer energy and water balance of polygonal tundra in the Lena River Delta, Siberia, J. Geophys. Res., 113, G03025, doi:10.1029/2007JG000540, 2008.

Blöschl, G. and Sivapalan, M.: Scale issues in hydrological modelling: A Review, Hydrol. Process., 9, 251-290, 1995.

Braud, I., Dantas-Antonino, A., Vauclin, M., Thony, J., and Ruelle, P.: A simple soil-plantatmosphere transfer model (SiSPAT) development and field verification, J. Hydrol., 166, 213250, 1995.

Brown, R. D. and Brasnett, B.: Canadian Meteorological Centre (CMC) Daily Snow Depth Anal15 ysis Data. ${ }^{\odot}$ Environment Canada, Boulder, Colorado USA: National Snow and Ice Data Center, 2010, updated annually.

Burke, E., Dankers, R., Jones, C. D., and Wiltshire, A.: A retrospective analysis of pan Arctic permafrost using the JULES land surface model, Clim. Dynam., 41, 1025-1038, doi:10.1007/s00382012-1648-x, 2013.

20 Carsel, R. and Parrish, R: Developing joint probability distributions of soil water retention characteristics, Water Resour. Res., American Geophysical Union, 24, 755-769, 1988.

Chalita, S.: Sensibilité du modèle de circulation atmosphérique LMD à l'albédo des surfaces enneigées, PhD Thesis, Université de Paris VI, 1992.

Ceballos, A., Scipal, K., Wagner, W., and Martinez-Fernandez, J.: Validation of ERS scatterometer-derived soil moisture data in the central part of the Duero Basin, Spain, Hydrol. Process., 19, 1549-1566, 2005.

Cresto Aleina, F., Brovkin, V., Muster, S., Boike, J., Kutzbach, L., Sachs, T., and Zuyev, S.: A stochastic model for the polygonal tundra based on Poisson-Voronoi diagrams, Earth Syst. Dynam., 4, 187-198, doi:10.5194/esd-4-187-2013, 2013.

30 Dankers, R., Burke, E. J., and Price, J.: Simulation of permafrost and seasonal thaw depth in the JULES land surface scheme, The Cryosphere, 5, 773-790, doi:10.5194/tc-5-773-2011, 2011.

Remotely-sensed

and modelled surface

soil moisture at high

latitudes

I. Gouttevin et al.

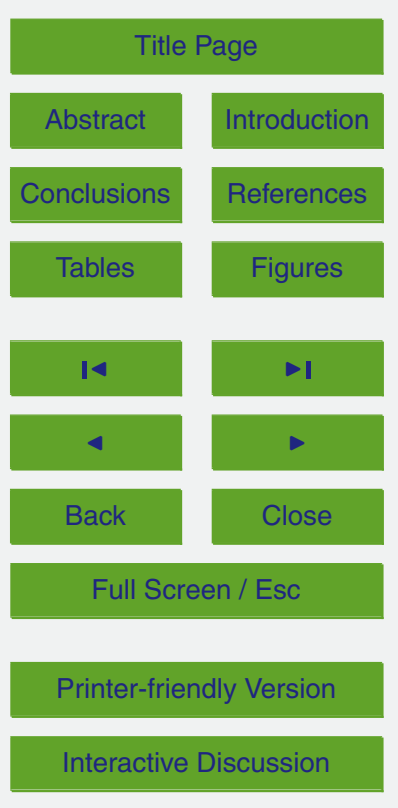


De Rosnay, P.: Representation of soil-vegetation-atmosphere interaction in the general circulation model of the Laboratoire de Météorologie Dynamique, PhD Thesis, Université de Paris VI, 1999.

Dee, D. P., Uppala, S. M., Simmons, A. J., Berrisford, P., Poli, P., Kobayashi, S., Andrae, U., Balmaseda, M. A., Balsamo, G., Bauer, P., Bechtold, P., Beljaars, A. C. M., van de Berg, L., Bidlot, J., Bormann, N., Delsol, C., Dragani, R., Fuentes, M., Geer, A.J., Haimberger, L., Healy, S. B., Hersbach, H., Holm, E. V., Isaksen, L., Kallberg, P., Köhler, M., Matricardi, M., McNally, A. P., Monge-Sanz, B. M., Morcrette, J.-J., Park, B.-K., Peubey, C., de Rosnay, P., Tavolato, C., Thépaut, J.-N., and Vitart, F.: The ERA-Interim reanalysis: configuration and performance of the data assimilation system, Q. J. Roy. Meteorol. Soc. A, 137, 553-597, 2011.

Dirnmeyer, P.: Problems in Initializing Soil Wetness, B. Am. Meteorol. Soc., 76, 2234-2240, 1995.

Dirmeyer, P., Gao, X., Zhao, M., Guo, Z., Oki, T., and Hanasaki, N.: GSWP-2: Multimodel analysis and implications for our perception of the land surface, B. Am. Meteorol. Soc., 87, 13811397, 2006.

d'Orgeval, T.: Impact du changement climatique sur le cycle de l'eau en Afrique de l'Ouest: Modélisation et incertitudes, PhD Thesis, Université de Paris VI, 2006.

Forster, P., Ramaswamy, V., Artaxo, P., Berntsen, T., Betts, R., Fahey, D. W., Haywood, J., Lean, J., Lowe, D. C., Myhre, G., Nganga, J., Prinn, R., Raga, G., Schulz, M., and Van Dorland, R.: Changes in Atmospheric Constituents and in Radiative Forcing, in: Climate Change 2007: The Physical Science Basis. Contribution of Working Group I to the Fourth Assessment Report of the Intergovernmental Panel on Climate Change, Cambridge University Press, Cambridge, UK and New York, NY, USA, 2007.

Fuchs, T., and Coauthors: GPCC annual report for year 2008: Development of the GPCC data base and analysis products. Global Precipitation Climatology Centre, 13 pp., available at: http://www.gpcc.dwd.de, 2009.

Gao, F., Schaaf, C., Strahler, A., Roesch, A., Lucht, W., and Dickinson, R.: MODIS bidirectional reflectance distribution function and albedo Climate Modeling Grid products and the variability of albedo for major global vegetation types, J. Geophys. Res., 110, D01104, doi:10.1029/2004JD005190, 2005.

Gedney, N. and Cox, P.: The sensitivity of global climate model simulations to the representation of soil moisture heterogeneity, J. Hydrometeorol., 4, 1265-1275, 2003.
HESSD

$10,11241-11291,2013$

Remotely-sensed

and modelled surface

soil moisture at high

latitudes

I. Gouttevin et al.

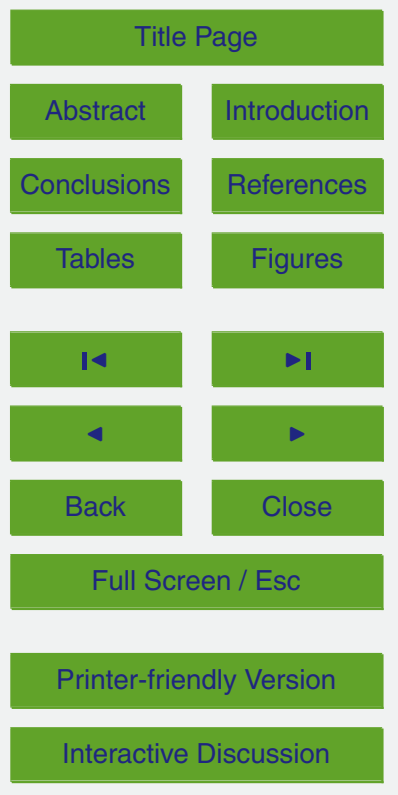


Georgakakos, K. P. and Baumer, O. W.: Measurement and utilization of on-site soil moisture data, J. Hydrol., 184, 131-152, 1996.

Gouttevin, I.: Contribution a la representation des hautes latitudes dans un modele de surface: gel des sols et diagnostics de performances, PhD Thesis, University of Grenoble, Grenoble,

5 France, 2012.

Gouttevin, I., Krinner, G., Ciais, P., Polcher, J., and Legout, C.: Multi-scale validation of a new soil freezing scheme for a land-surface model with physically-based hydrology, The Cryosphere, 6, 407-430, doi:10.5194/tc-6-407-2012, 2012.

Hall, D., Riggs, G., Foster, J., and Kumar, S.: Development and evaluation of a cloud-gap-filled MODIS daily snow-cover product, Remote Sens. Environ., Elsevier, 114, 496-503, 2010.

Hardy, J. E., Davis, R. E., Jordan, R., Ni, W., and Woodcock, C. E.: Snow ablation modeling in a mature aspen stand of the boreal forest, Hydrol. Process., 12, 1763-1778, 1998.

Heim, B., Bartsch, A., Elger, K., Lantuit, H., Boike, J., Muster, S., Langer, M., Duguay, C., Hachem, S., Soliman, A., Paulik, C., Strozzi, T., and Seifert, F. M.: ESA DUE Permafrost: An Earth observation (EO) permafrost monitoring system, EARSeL eProceedings, EARSeLlogo EARSeL European Association of Remote Sensing Laboratories, 10, 73-82, 2011.

Hillel, D.: Introduction to Soil Physics, Academic Press, San Diego etc., 365 p., 1980

Högström, E., Bartsch, A., and Gouttevin, I.: Quantifying impact of seasonal variations in backscatter on soil moisture retrieval in high latitude permafrost areas, EGU General Assembly, Vienna, Austria, 7-12 April 2013, EGU2013-7662, 2013.

Hugelius, G., Tarnocai, C., Broll, G., Canadell, J. G., Kuhry, P., and Swanson, D. K.: The Northern Circumpolar Soil Carbon Database: spatially distributed datasets of soil coverage and soil carbon storage in the northern permafrost regions, Earth Syst. Sci. Data, 5, 3-13, doi:10.5194/essd-5-3-2013, 2013.

Hulme, M. and New, M.: Dependence of large-scale precipitation climatologies on temporal and spatial sampling, J. Climate, 10, 1099-1113, 1997.

Jin, Y., Schaaf, C., Gao, F., Li, X., Strahler, A., Zeng, X., and Dickinson, R.: How does snow impact the albedo of vegetated land surfaces as analyzed with MODIS data?, Geophys. Res. Lett., American Geophysical Union, 29, 1374, 2002.

30 Jones, A., Stolbovoy, V., Tarnocai, C., Broll, G., Spaargaren, O., and Montanarella, L. (Eds.): Soil atlas of the Northern Circumpolar Region, European Commission, Publications Office of the European Union, Luxembourg, 144 pp., 2010.

Remotely-sensed

and modelled surface soil moisture at high

latitudes

I. Gouttevin et al.

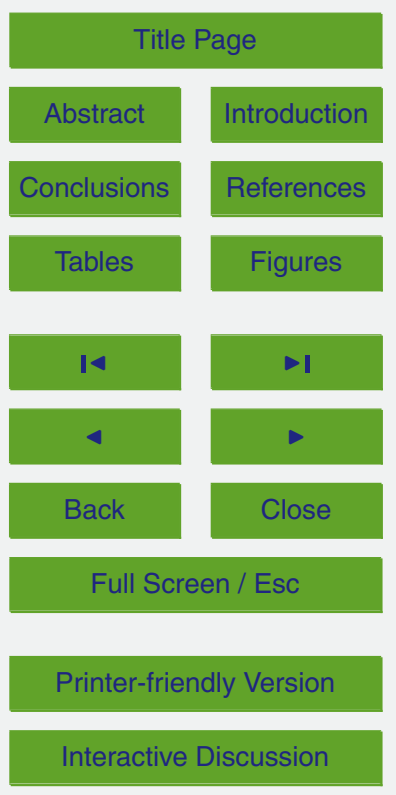


Kalnay, E., Kanamitsu, M., Kistler, R., Collins, W., Deaven, D., Gandin, L., Iredell, M., Saha, S., White, J., Woolen, J., Zhu, Y., Chelliah, M., Ebisuzaki, W., Higgins, W., Janoviak, J., Mo, K. C., Ropelewski, C., Wang, J., Leetmaa, A., Reynolds, R., Jenne, R., and Joseph, D.: The NCEP/NCAR 40-year reanalysis project, B. Am. Meteorol. Soc., 77, 437-471, 1996.

5 Koster, R. D., Guo, Z., Yang, R., Dirmeyer, P. A., Mitchell, K., and Puma, M. J.: On the nature of soil moisture in land surface models, J. Climate, 22, 4322-4335, 2009.

Legates, D.: A climatology of global precipitation, PhD Thesis, University of Delaware, 1988.

Lehner, B. and Döll, P.: Development and validation of a global database of lakes, reservoirs and wetlands, J. Hydrol., 296, 1-22, 2004.

10 Luo, L., Robock, A., Vinnikov, K., Schlosser, C., Slater, A., Boone, A., Etchevers, P., Habets, F., Noilhan, J., Braden, H., Cox, P., De Rosnay, P., Dickinson, R., Dai, Y., Duan, Q., Etchevers, P., Henderson-Sellers, A., Gedney, N., Gusev, Y., Habets, F., Kim, J., Kowalczyk, E., Mitchell, K., Nasonova, O., Noilhan, J., Pitman, A., Schaake, J., Shmakin, A., Smirnova, T., Wetzel, P., Xue, Y., Yang, Z., and Zeng, Q.: Effects of frozen soil on soil temperature, spring infiltration, and runoff: Results from the PILPS 2 (d) experiment at Valdaï, Russia, J. Hydrometeorol., 4, 334-351, 2003.

Marchenko, S., Romanovsky, V., and Tipenko, G.: Numerical modelling of spatial permafrost dynamics in Alaska, Proceedings of the Ninth International Conference on Permafrost, Fairbanks, Alaska, 28 June-3 July 2008, 1125-1130, 2008.

20 Martinez-Fernandez, J. and Ceballos, A.: Mean soil moisture estimation using temporal stability analysis, J. Hydrol., 312, 28-38, 2005.

Mitchell, T. and Jones, P.: An improved method of constructing a database of monthly climate observations and associated high-resolution grids, Int. J. Climatol., Wiley Online Library, 25, 693-712, 2005.

Naemi, V.: Model improvement and error characterization for global ERS and METOP scatterometer soil moisture data, $\mathrm{PhD}$ Thesis, Technische Universität Wien, 2009.

Naeimi, V., Bartalis, Z., and Wagner, W.: ASCAT soil moisture: An assessment of the data quality and consistency with the ERS scatterometer heritage, J. Hydrometeorol., 10, 555563, 2009a.

so Naemi, V., Scipal, K., Bartalis, Z., Hasenauer, S., and Wagner, W.: Improved Soil Moisture Retrieval Algorithm for ERS and METOP Scatterometer Observations, IEEE T. Geosci. Remote, 47, 1999-2013, 2009b.

Remotely-sensed and modelled surface soil moisture at high

latitudes

I. Gouttevin et al.

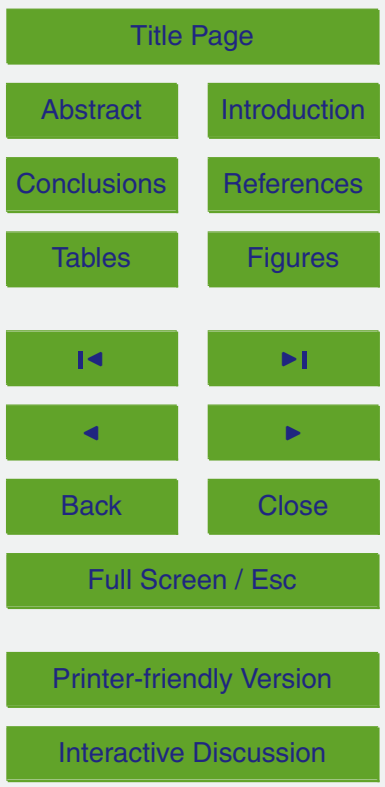


Naeimi, V., Paulik, C., Bartsch, A., Wagner, W., Kidd, R., Park, S., Elger, K., and Boike, J.: ASCAT Surface State Flag (SSF): Extracting Information on Surface Freeze/Thaw Conditions From Backscatter Data Using an Empirical Threshold-Analysis Algorithm, IEEE T. Geosci. Remote, 50, 2566-2582, 2012.

5 Nash, J. and Sutcliff, J.: River flow forecasting through conceptual models, part I - A: Discussion of principles, J. Hydrol., 10, 282-290, 1970.

Oberbauer, S. F., Starr, G., and Pop, E. W.: Effects of extended growing season and soil warming on carbon dioxide and methane exchange of tussock tundra in Alaska, J. Geophys. Res., 103, 29075-29082, doi:10.1029/98JD00522, 1998.

10 New, M., Hulme, M., and Jones, P.: Representing twentieth-century space-time climate variability. Part I: Development of a 1961-90 mean monthly terrestrial climatology, J. Climate, 12, 829-856, 1999.

Nijssen, B., Bowling, L. C., Lettenmaier, D. P., Clark, D. B., El Maayar, M., Essery, R., Goers, S., Gusev, Y.M., Habets, F. van den Hurk, B., Jin, J., Kahan, D., Lohmann, D., Ma, X., Mahanama, S., Mocko, D., Nasonova, O., Niu, G.-Y., Samuelsson, P., Shmakin, A. B., Takata, K., Verseghy, D., Viterbo, P., Xia, Y., Xue, Y., and Yang, Z.-Y.: Simulation of high latitude hydrological processes in the Torne-Kalix basin: PILPS Phase 2(e) 2: Comparison of model results with observations, Global Planet. Change, 38, 31-53, 2003.

Niu, G. and Yang, Z.: Effects of frozen soil on snowmelt runoff and soil water storage at a continental scale, J. Hydrometeorol., 7, 937-952, 2006.

Parajka, J., Naeimi, V., Blöschl, G., Wagner, W., Merz, R., and Scipal, K.: Assimilating scatterometer soil moisture data into conceptual hydrologic models at the regional scale, Hydrol. Earth Syst. Sci., 10, 353-368, doi:10.5194/hess-10-353-2006, 2006.

Paulik, C., Melzer, T., Hahn, S., Bartsch, A., Heim, B., Elger, K., and Wagner, W.: Circumpolar surface soil moisture and freeze/thaw surface status remote sensing products with links to geotiff images and netCDF files, Institute of Photogrammetry and Remote Sensing, TU Vienna, 2012.

Reichle, R. and Koster, R.: Global assimilation of satellite surface soil moisture retrievals into the NASA Catchment land surface model, Geophys. Res. Lett., 32, L02404, doi:10.1175/15257541(2004)005<0430:GSMFSO>2.0.CO;2, 2005.

Reynolds, C., Jackson, T., and Rawls, W. J.: Estimating available water content by linking the fao soil map of the world with global soil profile databases and pedo-transfer functions, Proceedings of the AGU Spring Conference, 1-4 June 1999, Boston, MA., 80-96, 1999.
HESSD

10, 11241-11291, 2013

Remotely-sensed and modelled surface soil moisture at high

latitudes

I. Gouttevin et al.

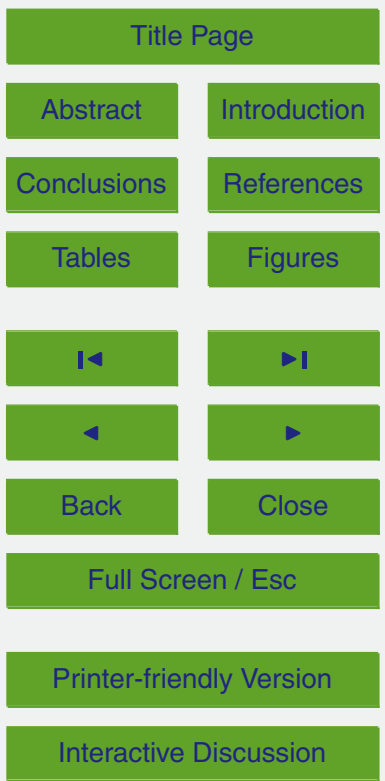


Ringeval, B., Decharme, B., Piao, S. L., Ciais, P., Papa, F., de Noblet-Ducoudré, N., Prigent, C., Friedlingstein, P., Gouttevin, I., Koven, C., and Ducharne, A.: Modelling sub-grid wetland in the ORCHIDEE global land surface model: evaluation against river discharges and remotely sensed data, Geosci. Model Dev., 5, 941-962, doi:10.5194/gmd-5-941-2012, 2012.

5 Saha, S., Moorthi, S., Pan, H., Wu, X., Wang, J., Nadiga, S., Tripp, P., Kistler, R., Woollen, J., Behringer, D., Liu, H., Stokes, D., Grumbine, R., Gayno, G., Wang, J., Hou, Y-T., Chuang, H., Juang, H-M. H., Sela, J., Iredell, M., treadon, R., Kleist, D., Van Delst, P., Keyser, D., Derber, J., Ek, M., Meng, J., Wei, H., Yang, R., Lord, S., van den Dool, H., Kumar, A., Wang, W., Long, C., Chelliah, M., Xue, Y., Huang, B., Schemm, J-K., Ebisuzaki, W., Lin, R., Xie, P., Chen, M., Zhou, S., Higgins, W., Zou, C.-Z., Liu, Q., Chen, Y., Han, Y., Cucurull, L., Reynolds, R. W., Rutledge, G., and Goldberg, M.: The NCEP climate forecast system reanalysis, B. Am. Meteorol. Soc., 91, 1015-1057, 2010.

Schulin, R., Flühler, H., Selim, H. M., Sevruk, B., and Wierenga, J. P.: Soil Moisture, Part III, in : Snow cover measurements and areal assessment of precipitation and soil moisture, edited 15 by B. Sevruk, WMO, Operational Hydrological Report, 55, 219-283, 1992.

Schuur, E. A. G., Bockheim, J., Canadell, E. E., Field, C. B., Goryachkin, S. V., Hagemann, S., Kuhry, P., Lafleur, P. M., Lee, H., Mazhitova, G., Nelson, F. E., Rinke, A., Romanovsky, V.E., Shiklomanov, N., Tarnocai, C., Venevsky, J. G., and Zimov, S. A.: Vulnerability of permafrost carbon to climate change: Implications for the global carbon cycle, BioScience, 58, 701-714, doi:10.1641/B580807, 2008.

Scipal, K., Drusch, M., and Wagner, W.: Assimilation of a ERS scatteromètre derived soil moisture index in the ECMWF numerical weather prediction system, Adv. Water Resour., 31, 1101-1112, 2008.

Schlosser, C. A., Slater, A. G., Robock, A., Pitman, A. J., Vinnikov, K. Y., Henderson-Sellers, 25 A., Speranskaya, N. A., Mitchell, K., Boone, A., Baden, H., Chen, F., Cox, P., de Rosnay, P., Desborough, C. E., Dickenson, R. E., Dai, Y., Duan, Q., Entin, J., Etchevers, P., Gedney, N., Gusev, Y., Habets, F., Kim, J., Koren, V., Kowalczyk, E., Nasonova, O., Noilhan, J., Schaake, J., Shmakin, A. B., Smirnova, T. G., Verseghy, D., Wetzel, P., Xue, Y., and Yang, Z.: Standalone simulations of a boreal hydrology with land surface schemes used in atmospheric models: PILPS Phase 2(d), Mon. Weather Rev., 128, 301-321, 2000.

Serreze, M., Bromwich, D., Clark, M., Etringer, A., Zhang, T., and Lammers, R.: Large-scale hydro-climatology of the terrestrial Arctic drainage system, J. Geophys. Res., 108, 81608187, 2003.

\section{HESSD}

$10,11241-11291,2013$

Remotely-sensed

and modelled surface soil moisture at high

latitudes

I. Gouttevin et al.

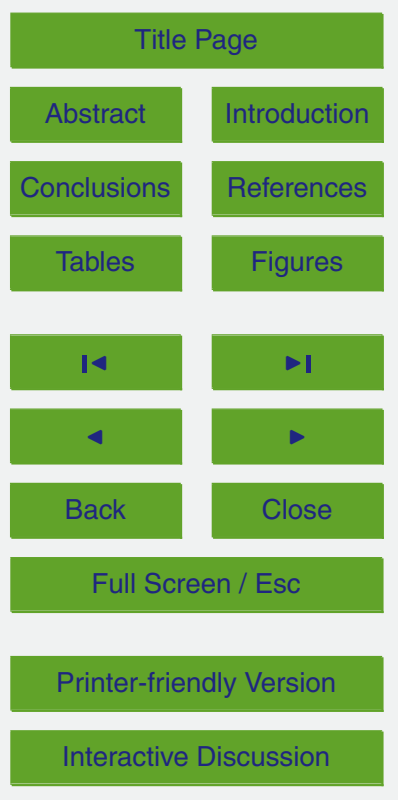


Sheffield, J., Goteti, G., and Wood, E.: Development of a 50-year high-resolution global dataset of meteorological forcings for land surface modelling, J. Climate, 19, 3088-3111, 2006.

Sitch, S., Smith, B., Prentice, I. C., Arneth, A., Bondeau, A., Cramer, W. Kaploan, J. O., Lewis, S., Lucht, W., Sykes, M. T., Thonicke, K., and Venevsky, S.: Evaluation of ecosystem dy5 namics, plant geography and terrestrial carbon cycling in the LPJ dynamic global vegetation model, Global Change Biol., 9, 161-185, 2003.

Slater, A., Smirnova, T., Schlosser, C., Desborough, C., Pitman, A., Henderson-Sellers, A., Robock, A., Vinnikov, K., Entin, J., Mitchell, K., Boone, A., Braden, H., Chen, F., Cox, P. M., de Rosnay, P., Dickinson, R. E., Dai, Y.-J., Duan, Q., Entin, J., Etchevers, P., Gedney, N., Gusev, Y.M., Habets, F., Kim, J., Koren, V., Kowalczyk, E. A., Nasonova, O. N., Noihlan, J., Schaake, S., Shmakin, A. B., Smirnova, T. G., Verseghy, D., Wetzel, P., Xue, Y., Yang, Z.-L., and Zeng, Q.: The Representation of snow in land surface schemes: Results from PILPS 2 (d), J. Hydrometeorol., 2, 7-25, 2001.

Solberg, R., Wangensteen, B., Metsämäki, S., Nagler, T., Sandner, R., Rott, H., Wiesmann, A., 15 Luojus, K., Kangwa, M., and Pulliainen, J.: GlobSnow Snow Extent Product Guide Product Version 1.0, European Space Agency Study Contract Report, ESRIN Contract 21703/08/IEC, 2010.

Takala, M., Luojus, K., Pulliainen, J., Derksen, C., Lemmetyinen, J., Kärnä, J., Koskinen, J., and Bojkov, B.: Estimating northern hemisphere snow water equivalent for climate research through assimilation of space-borne radiometer data and ground-based measurements, Remote Sens. Environ., Elsevier, 115, 3517-3529, 2011.

Tarnocai, C., Canadell, J., Schuur, E., Kuhry, P., Mazhitova G., and Zimov, S.: Soil organic carbon pools in the northern circumpolar permafrost region, Global Biogeochem. Cy., 23, GB2013, doi:10.1029/2008GB003327, 2009.

Topp, G. C.: The measurement and monitoring of soil water content by TDR, in: Soil Moisture Modelling, Proceedings of the National Hydrology Research Centre Workshop, Saskatoon, Saskatechewan, Canada, 9-10 March, 155-161, 1992.

Ulaby, F., Moore, R., and Fung, A.: Radar Remote Sensing and Surface Scattering and Emission Theory, Vol. 2 of Microwave Remote Sensing: Active and Passive, Addison-Wesley, 30 1982

Viovy, N. and Ciais, P.: CRUNCEP data set for 1901-2008, Technical Report Version 4, Laboratoire des Sciences du Climat et de l'Environnement, available at: http://dods.extra.cea.fr/ data/p529viov/cruncep/, 2012. 
Vivant, A.: L'écoulement latéral de l'eau sur les surfaces continentales, Master's thesis, Université de Paris VI, 2003.

Wagner, W., Bloschl, G., Pampaloni, P., Calvet, J., Bizzarri, B., Wigneron, J., and Kerr, Y.: Operational readiness of microwave remote sensing of soil moisture for hydrologic applications, Nord. Hydrol., 38, 1-20, 2007 a.

Wagner, W., Lemoine, G., and Rott, H.: A method for estimating soil moisture from ERS scatterometer and soil data, Remote Sens. Environ., Elsevier, 70, 191-207, 1999.

Wagner, W., Naeimi, V., Scipal, K., De Jeu, R., and Fernandez-Martinez, J.: Soil moisture from operational meteorological datasets, J. Hydrol., 15, 121-131, 2007b.

10 Wagner, W., Pathe, C., Doubkova1, M., Sabel, D., Bartsch, A., Hasenauer, S., Blöschl, G., Scipal, K., Martínez-Fernández, J., and Löw, A.: Temporal Stability of Soil Moisture and Radar Backscatter Observed by the Advanced Synthetic Aperture Radar (ASAR), Sensors, 8, 1174-1197, 2008.

Wagner, W., Scipal, K., Pathe, C., Gerten, D., Lucht, W., and Rudolf, B.: Evaluation of the agreement between the first global remotely-sensed soil moisture data with model and precipitation data, J. Geophys. Res., 108, ACL 9-1-9-15, 2003.

Walker, J. and Houser, P.: Requirements of a global near-surface soil moisture satellite mission: accuracy, repeat time, and spatial resolution, Adv. Water Resour., Elsevier, 27, 785-801, 2004.

20 Wang, T., Ottle, C., Boone, A., Ciais, P., Brun, E., Morin, S., Krinner, S. Piao, and Peng, S.: Evaluation of an improved intermediate complexity snow scheme in the ORCHIDEE land surface model, J. Geophys. Res., 118, 6064-6079, doi:10.1002/jgrd.50395, 2013.

Weedon, G., Gomes, S., Viterbo, P., Shuttleworth, W., Blyth, E., Österle, H., Adam, J., Bellouin, N., Boucher, O., and Best, M.: Creation of the WATCH Forcing Data and its use to assess global and regional reference crop evaporation over land during the twentieth century, J. Hydrometeorol., 12, 823-848, 2011.

Western, A., Grayson, R., and Blöschl, G.: Scaling of soil moisture: a hydrologic perspective, Annu. Rev. Earth PI. Sc., 30, 149-180, 2002.

Yang, K., Watababe, T., Koike, T., Li, X., Fujii, H., Tamagawa, K., Ma, Y., and Ishikawa, H.: 30 Auto-calibration system developed to assimilate AMSR-E data into a land-surface model for estimating soil moisture and the surface energy budget, J. Meteorol. Soc. Jpn., 85, 229-242, 2007.

Remotely-sensed and modelled surface soil moisture at high latitudes

I. Gouttevin et al.

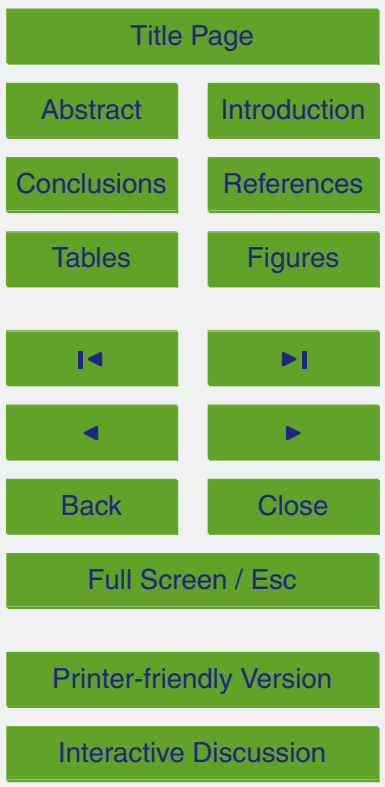


Zhang, T., Barry, R., Knowles, K., Heginbottom, J., and Brown, J.: Statistics and characteristics of permafrost and ground-ice distribution in the Northern Hemisphere, Polar Geography, Taylor and Francis, 31, 47-68, 2008.

Zobler, L.: A world soil file for global climate modelling, NASA technical memorandum, 87802, $5 \quad 1986$

\section{HESSD}

$10,11241-11291,2013$

Remotely-sensed and modelled surface soil moisture at high latitudes

I. Gouttevin et al.

Title Page

Abstract Introduction

Conclusions References

14

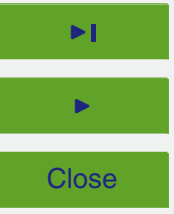

Back

Full Screen / Esc

Printer-friendly Version

Interactive Discussion 


\section{HESSD}

\section{0, 11241-11291, 2013}

\section{Remotely-sensed}

and modelled surface soil moisture at high latitudes

I. Gouttevin et al.

Table 1. Agreement (in percent) between modelled and remotely-sensed surface status over the days of the 2007-2009 period with satellite acquisitions. In brackets: mean number of days in a year season ${ }^{-1}$ with remote-sensing information of the specific surface status.

\begin{tabular}{lrrrrr}
\hline $\begin{array}{l}\text { Time-span } \\
\text { Surface status }\end{array}$ & All year & Winter & Spring & Summer & Fall \\
\cline { 2 - 6 } frozen & $79(177.2)$ & $99(71.4)$ & $86(23.8)$ & $31(6.4)$ & $99(75.7)$ \\
unfrozen & $42(164.3)$ & $3(9.5)$ & $60(55.1)$ & $91(85.3)$ & $13(15.2)$ \\
\hline
\end{tabular}

Title Page

Abstract Introduction

Conclusions References

Tables Figures

14

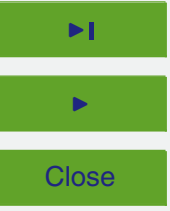

Back

Full Screen / Esc

Printer-friendly Version

Interactive Discussion 
Table 2. Model shortcomings pertaining to specific regions of our study area.

\begin{tabular}{|c|c|c|c|}
\hline Region & $\begin{array}{l}\text { Western Siberia } \\
\text { (excluding Taymyr) }\end{array}$ & $\begin{array}{l}\text { Mountain Ranges (Ural, } \\
\text { Verkhoyansk, Putorana, } \\
\text { Baikal, Altai, Kolyma) }\end{array}$ & $\begin{array}{l}\text { Eastern Siberia (Eastern } \\
\text { part of the Central Siberian } \\
\text { Plateau, Sakha, Tchukotka) }\end{array}$ \\
\hline Landscape & $\begin{array}{l}\text { Lowlands subjects } \\
\text { to ponding, lakes }\end{array}$ & Relief, rocky soils & $\begin{array}{l}\text { Low-altitude relief, } \\
\text { occurrence of barren, rocky } \\
\text { shallow soils, numerous lakes }\end{array}$ \\
\hline $\begin{array}{l}\text { Dominant model } \\
\text { bias(es) }\end{array}$ & Low SSM & High SSM Undue soil drying & Undue soil moistening \\
\hline $\begin{array}{l}\text { Hydrological } \\
\text { modelling } \\
\text { shortcomings }\end{array}$ & $\begin{array}{l}\text { - no ponding, no } \\
\text { floodplains }\end{array}$ & $\begin{array}{l}\text { - no representation of the } \\
\text { hydrological specificities of } \\
\text { mountain areas } \\
\text { - misrepresented } \\
\text { (underestimated) } \\
\text { precipitation }\end{array}$ & $\begin{array}{l}\text { - poor representation of soil } \\
\text { hydrological characteristics } \\
\text { - high uncertainties in } \\
\text { meteorological forcing, } \\
\text { especially precipitation }\end{array}$ \\
\hline
\end{tabular}

Remotely-sensed and modelled surface soil moisture at high latitudes

I. Gouttevin et al.

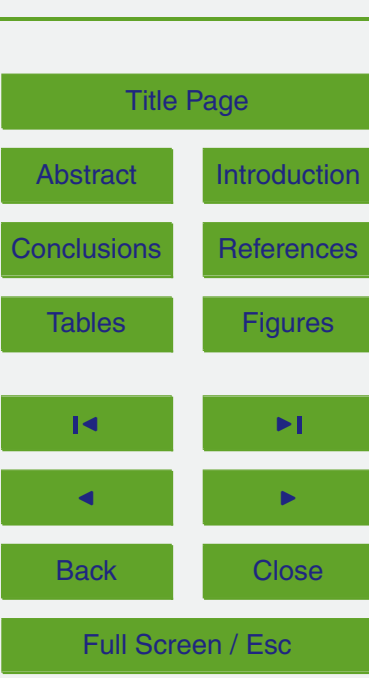

Printer-friendly Version

Interactive Discussion 


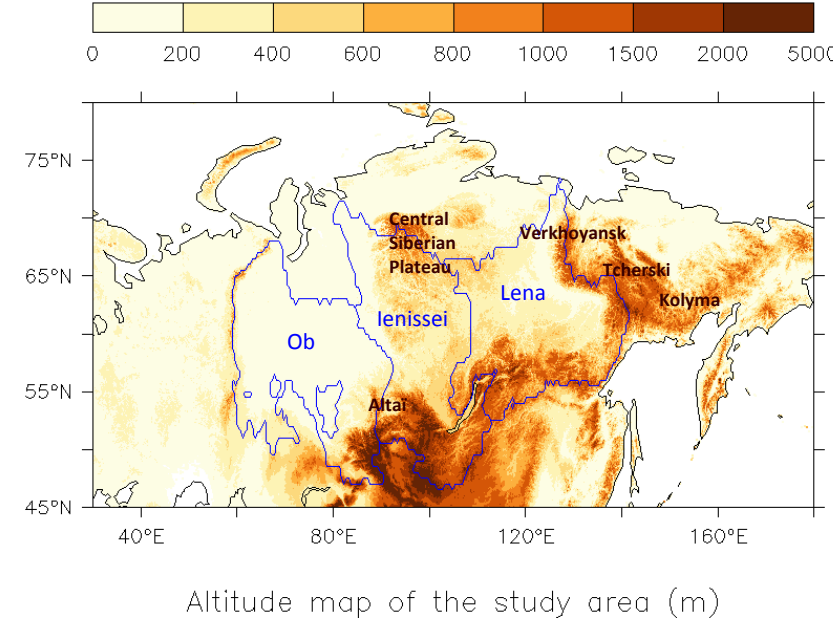

Fig. 1. Topography of the study area, its main basins and mountain ranges.

\section{HESSD}

10, 11241-11291, 2013

Remotely-sensed and modelled surface soil moisture at high latitudes

I. Gouttevin et al.

Title Page

Abstract Introduction

Conclusions

References

Tables

Figures

14

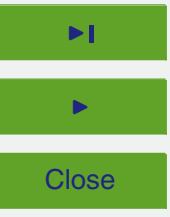

Back

Full Screen / Esc

Printer-friendly Version

Interactive Discussion 


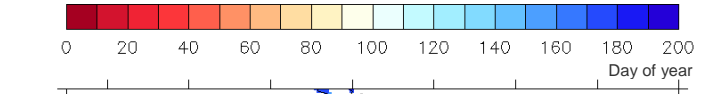

HESSD

10, 11241-11291, 2013

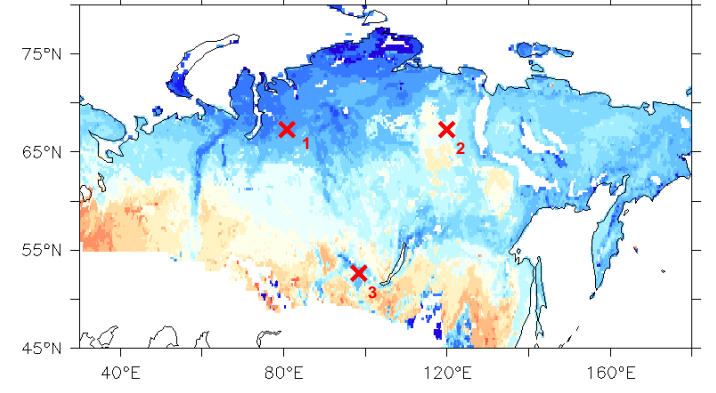

Remotely-sensed and modelled surface soil moisture at high latitudes

I. Gouttevin et al.

a. ASCAT - Last day of thaw

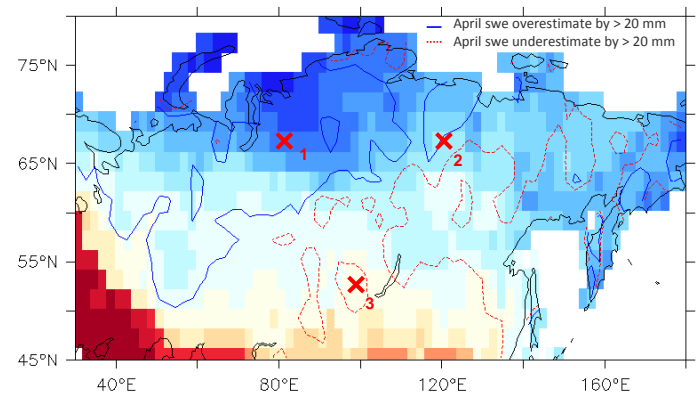

Title Page

Abstract Introduction

Conclusions References

Tables

Figures

14

4

b.

MODEL - Last day of thaw

Fig. 2. Remotely-sensed (a) and modelled (b) day-of-year of surface thaw for the year 2007. See text for the precise definition of this timing. Overlain on (b) are the contours of regions where the mean modelled snow water equivalent for April 2007 is overestimated (blue line) and underestimated (dashed red line) by more than $20 \mathrm{~mm}$ with respect to CMC data. Model biases are analysed at locations 1,2 and 3. 


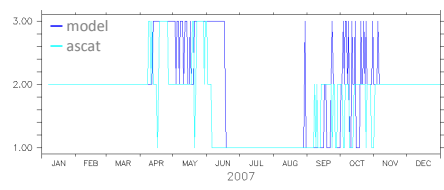

MODEL and ASCAT surface status (80E. 67N)

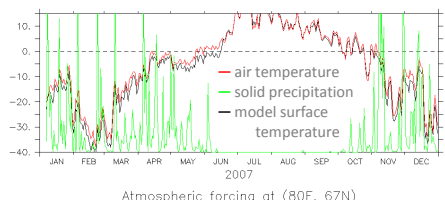

Atmospheric forcina at (80E, 67N

a.

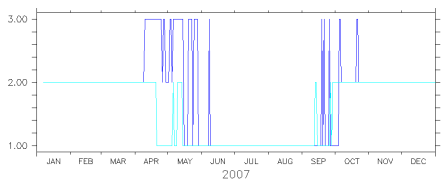

MODEL and ASCAT surface status (120E. 67N)

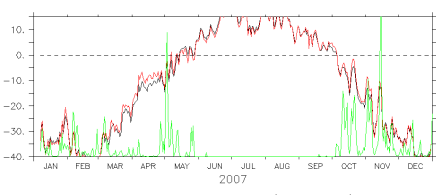

Atmospheric forcina at $(120 E, 67 \mathrm{~N})$

b. $\quad$ location 2

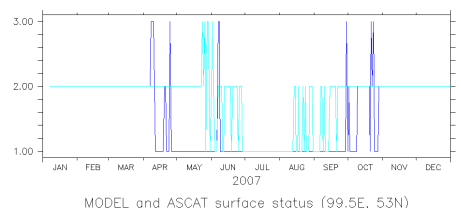

MODEL and ASCAT surface status (99.5E. 53N)

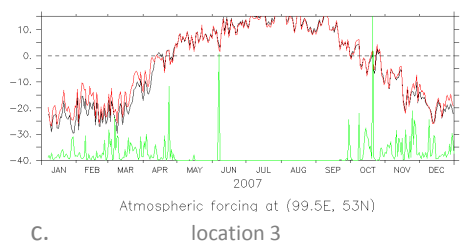

Fig. 3. Modelled and remotely-sensed surface status (top images) and atmospheric forcing data (bottom images) at location 1 (a), 2 (b) and 3 (c); these locations are shown on Fig. 2. Code for the surface status is: 3 for melting snow; 2 for frozen ground conditions; 1 for unfrozen surface. Also shown on the bottom images are modelled surface temperature (black, plain) and freezing point isotherms (black, dash).

\section{HESSD}

10, 11241-11291, 2013

Remotely-sensed and modelled surface soil moisture at high latitudes

\section{Gouttevin et al.}

\section{Title Page}

Abstract Introduction

Conclusions

References

Tables

Figures

14

I

4

Back

Close

\section{Full Screen / Esc}

Printer-friendly Version

Interactive Discussion 


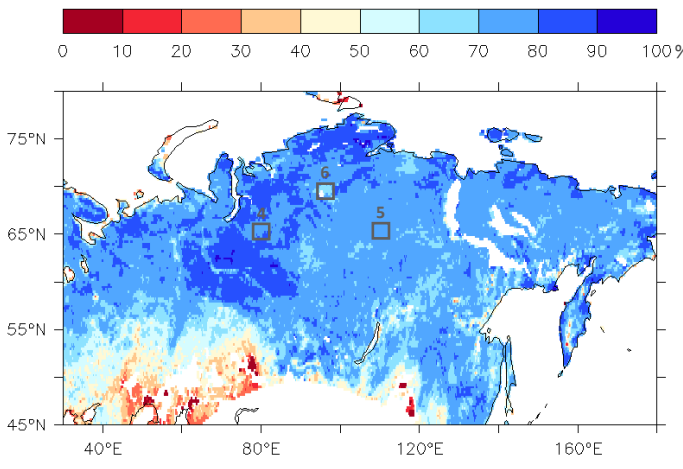

HESSD

10, 11241-11291, 2013

Remotely-sensed and modelled surface soil moisture at high latitudes

I. Gouttevin et al.

a. ASCAT mean annual surface soil moisture, 2007-2009

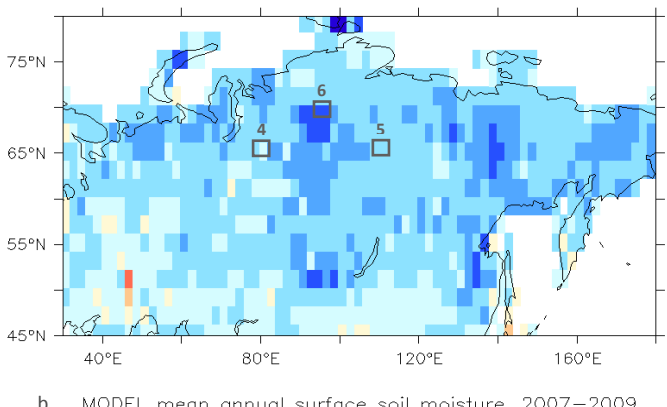

Abstract

Conclusions

\section{Tables}

14

4

\section{Back}

Full Screen / Esc

Printer-friendly Version

Interactive Discussion 


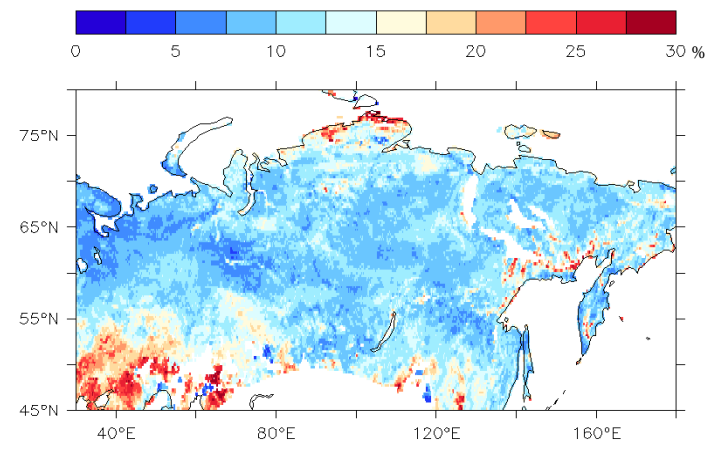

\section{HESSD}

$10,11241-11291,2013$

\section{Remotely-sensed and modelled surface soil moisture at high latitudes \\ I. Gouttevin et al.}

a. ASCAT soil moisture std. dev., 2007-2009

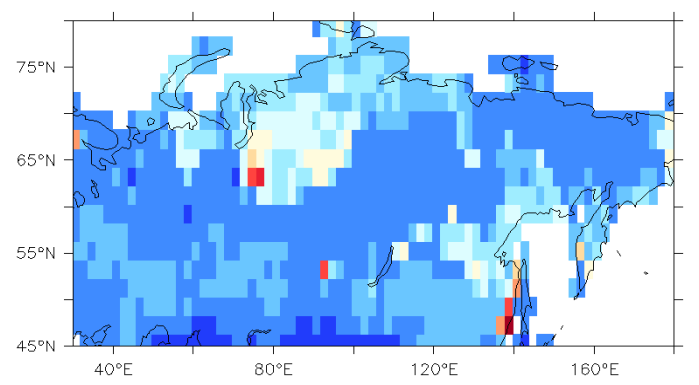

b. MODEL soil moisture variance, 2007-2009

Fig. 5. Mean annual standard deviation (\%) of the surface soil moisture index derived from the ASCAT sensor (a) and from model outputs (b) over 2007-2009.

Title Page

Abstract

Introduction

Conclusions

References

Tables

Figures

14

4

Back

Full Screen / Esc

Printer-friendly Version

Interactive Discussion 


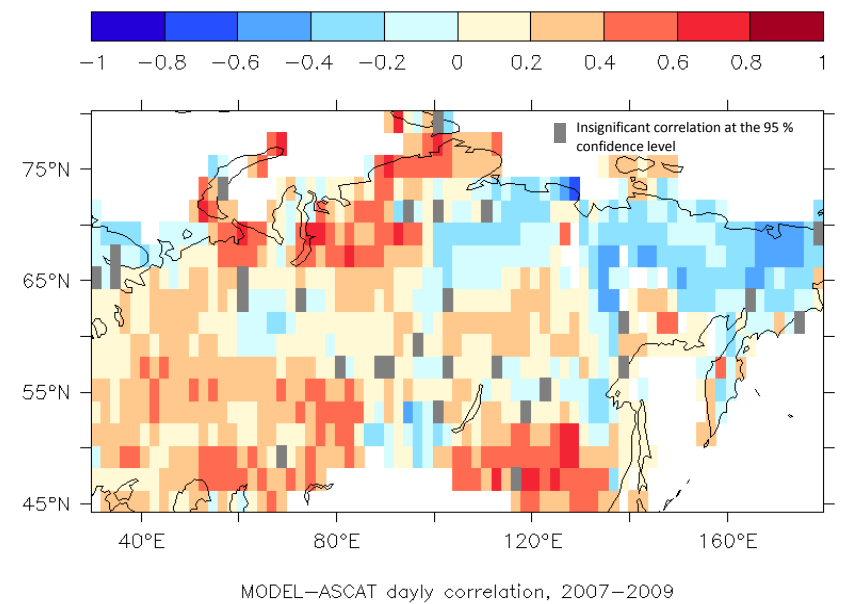

Fig. 6. Modelled and remotely-sensed SSM daily correlation coefficient over 2007-2009.

\section{HESSD}

10, 11241-11291, 2013

Remotely-sensed and modelled surface soil moisture at high latitudes

I. Gouttevin et al.

Title Page

Abstract Introduction

Conclusions

References

Tables

Figures

14

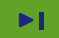

Back

Full Screen / Esc

Printer-friendly Version

Interactive Discussion 


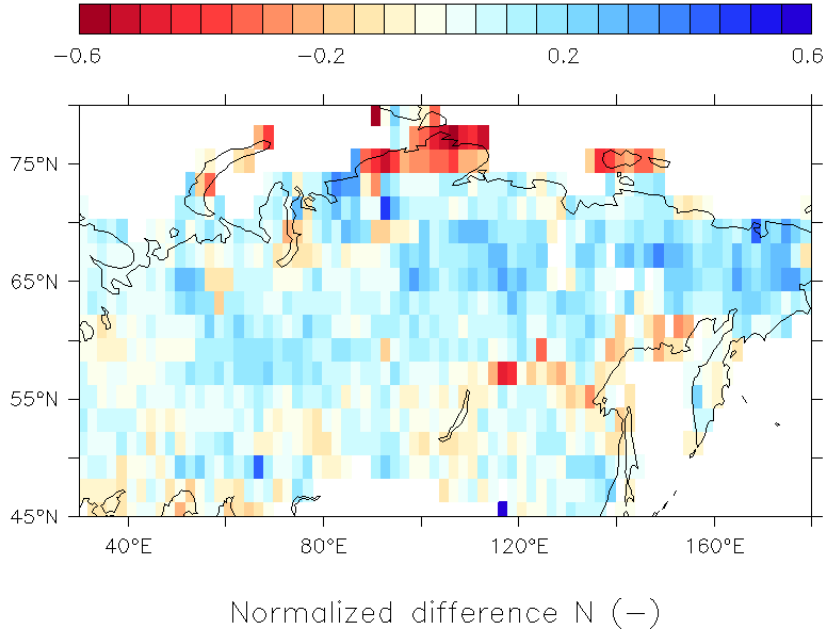

Fig. 7. Normalized difference between days showing undue surface moistening and undue surface drying in the model with respect to the ASCAT SSM product.

\section{HESSD}

10, 11241-11291, 2013

Remotely-sensed and modelled surface soil moisture at high latitudes

\section{Gouttevin et al.}

Title Page

Abstract Introduction

Conclusions

References

Tables

Figures

14

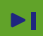

Back

Close

Full Screen / Esc

Printer-friendly Version

Interactive Discussion 


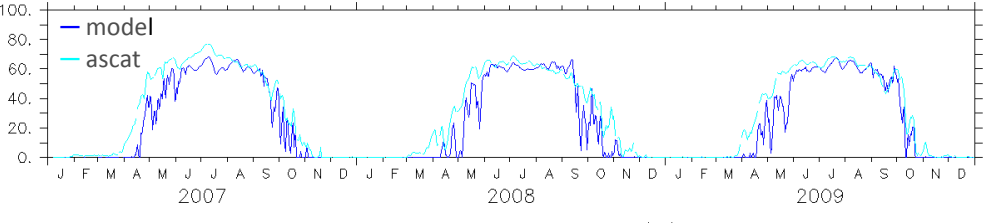

Ob-basin SSM dvnamics (-)

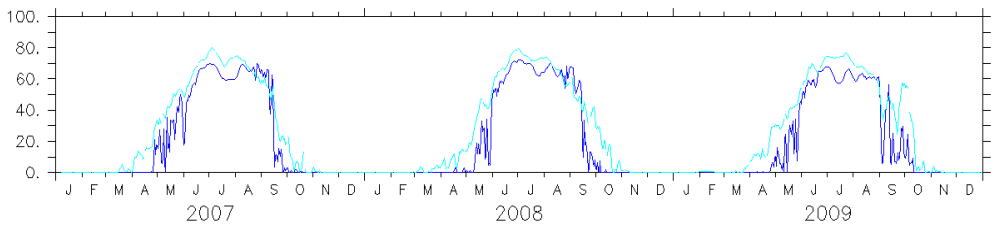

lenissei-basin SSM dynamics (-)

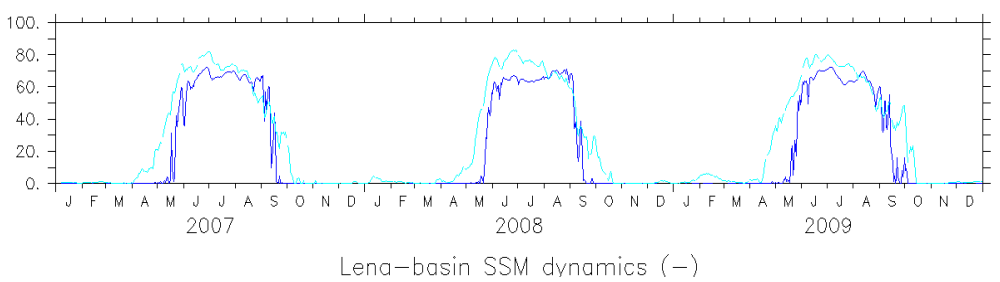

Fig. 8. Remotely-sensed and modelled SSM (\%), averaged over the three main basins of the study area.

\section{HESSD}

10, 11241-11291, 2013

Remotely-sensed and modelled surface soil moisture at high latitudes

I. Gouttevin et al.

Title Page

Abstract Introduction

Conclusions

References

Tables

Figures

14

$\rightarrow$

4

Back

Close

Full Screen / Esc

Printer-friendly Version

Interactive Discussion 

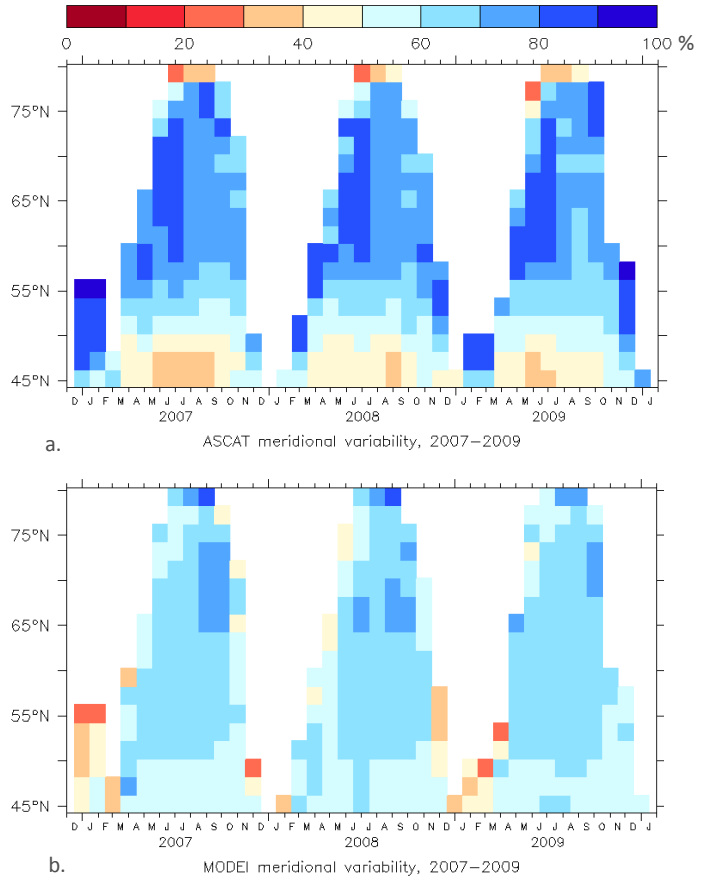

Fig. 9. Seasonal evolution of the zonal mean remotely-sensed (a) and modelled (b) SSM (\%) over the 2007-2009 period.

\section{HESSD}

$10,11241-11291,2013$

Remotely-sensed and modelled surface soil moisture at high latitudes

I. Gouttevin et al.

Title Page

Abstract Introduction

Conclusions References

Tables

Figures

14 $>1$

4

Back

Close

Full Screen / Esc

Printer-friendly Version

Interactive Discussion 


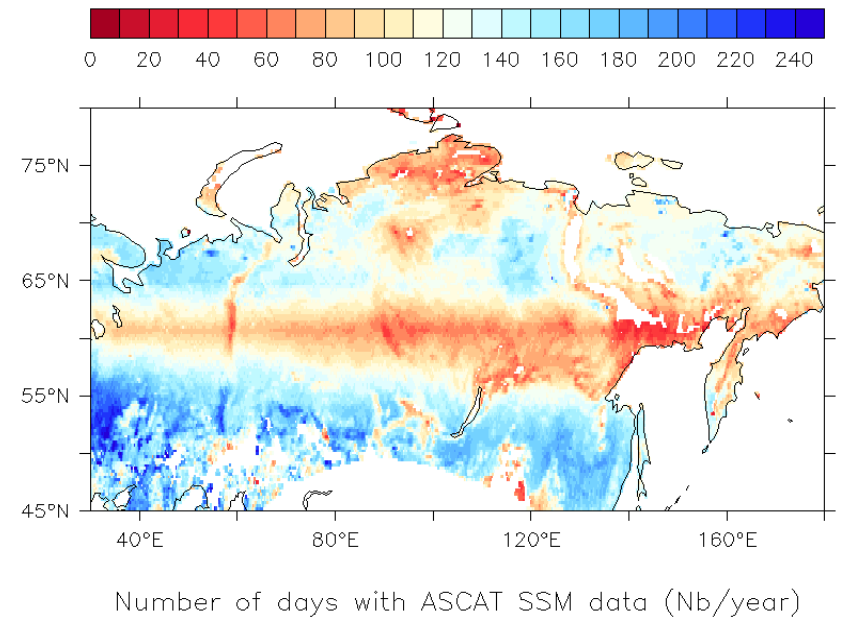

Fig. A1. Mean number of days a year with ASCAT SSM data over 2007-2009.

$10,11241-11291,2013$

Remotely-sensed and modelled surface soil moisture at high latitudes

I. Gouttevin et al.

Title Page

Abstract Introduction

Conclusions

References

Tables

Figures

14

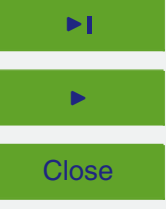

Back

Full Screen / Esc

Printer-friendly Version

Interactive Discussion 


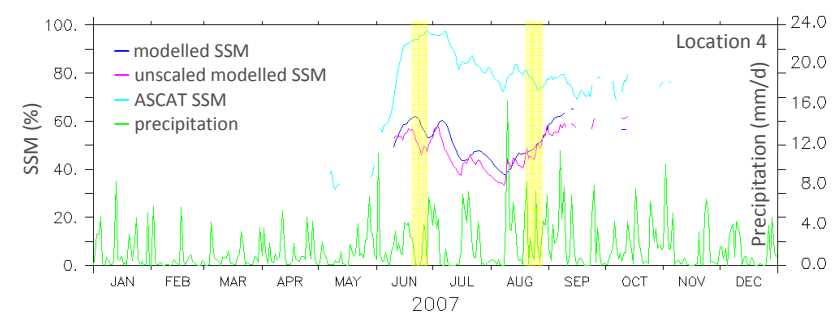

a. Soil moisture dynamics in the W. Siberian Lowlands around $80 \mathrm{E}, 66 \mathrm{~N}$.

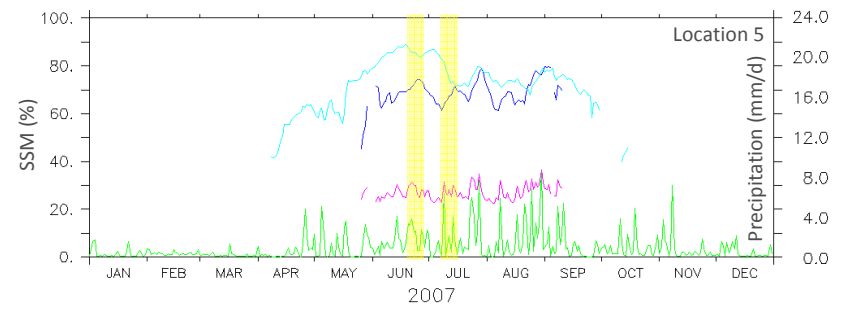

b. Soil moisture dynamics in Central Siberia around $110 \mathrm{E}, 66 \mathrm{~N}$

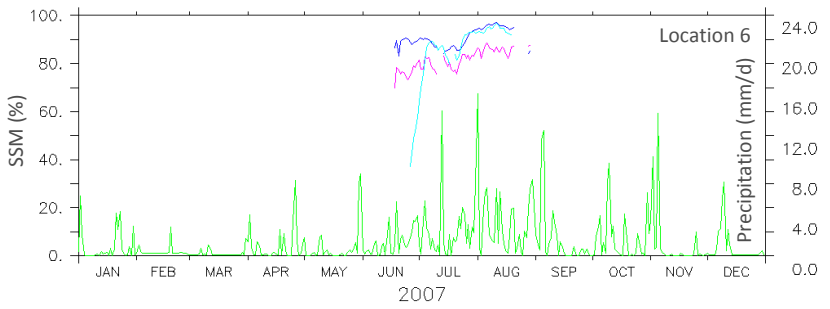

c. Soil maisture dynamics in the Central Siberian Plateau around $96.5 \mathrm{E}, 69.5 \mathrm{~N}$

Fig. A2. Temporal dynamics of the remotely-sensed and modelled liquid soil moisture indices (SSM) at locations 4 (a), 5 (b) and 6 (c). These regions are identified on Fig. 4. The unscaled modelled SSM refers to the real-time modelled saturation degree, on which neither scaling nor temporal averaging has been performed. Also shown are precipitations indicated by the climate forcing (green). Periods of correlation and anti-correlation between model outputs and ASCAT data are highlighted on (a) and (b).

\section{HESSD}

10, 11241-11291, 2013

Remotely-sensed and modelled surface soil moisture at high latitudes

\section{Gouttevin et al.}

Title Page

Abstract Introduction

Conclusions References

Tables Figures

14 $\rightarrow 1$

4

Back

Close

\section{Full Screen / Esc}

Printer-friendly Version

Interactive Discussion 